\title{
Dissecting the Hormonal Signaling Landscape in Castration-Resistant Prostate Cancer
}

\author{
Fabrizio Fontana and Patrizia Limonta *(D) \\ Department of Pharmacological and Biomolecular Sciences, Università degli Studi di Milano, 20133 Milano, Italy; \\ fabrizio.fontana@unimi.it \\ * Correspondence: patrizia.limonta@unimi.it; Tel.: +39-02-50318213
}

check for

updates

Citation: Fontana, F.; Limonta, P. Dissecting the Hormonal Signaling Landscape in Castration-Resistant Prostate Cancer. Cells 2021, 10, 1133. https://doi.org/10.3390/cells10051133

Academic Editor: Günter Emons

Received: 8 April 2021

Accepted: 6 May 2021

Published: 7 May 2021

Publisher's Note: MDPI stays neutral with regard to jurisdictional claims in published maps and institutional affiliations.

Copyright: (c) 2021 by the authors. Licensee MDPI, Basel, Switzerland. This article is an open access article distributed under the terms and conditions of the Creative Commons Attribution (CC BY) license (https:/ / creativecommons.org/licenses/by/ $4.0 /)$.

\begin{abstract}
Understanding the molecular mechanisms underlying prostate cancer (PCa) progression towards its most aggressive, castration-resistant (CRPC) stage is urgently needed to improve the therapeutic options for this almost incurable pathology. Interestingly, CRPC is known to be characterized by a peculiar hormonal landscape. It is now well established that the androgen/androgen receptor (AR) axis is still active in CRPC cells. The persistent activity of this axis in PCa progression has been shown to be related to different mechanisms, such as intratumoral androgen synthesis, AR amplification and mutations, AR mRNA alternative splicing, increased expression/activity of ARrelated transcription factors and coregulators. The hypothalamic gonadotropin-releasing hormone (GnRH), by binding to its specific receptors (GnRH-Rs) at the pituitary level, plays a pivotal role in the regulation of the reproductive functions. GnRH and GnRH-R are also expressed in different types of tumors, including PCa. Specifically, it has been demonstrated that, in CRPC cells, the activation of GnRH-Rs is associated with a significant antiproliferative/proapoptotic, antimetastatic and antiangiogenic activity. This antitumor activity is mainly mediated by the GnRH-R-associated $\mathrm{G} \alpha \mathrm{i} / \mathrm{cAMP}$ signaling pathway. In this review, we dissect the molecular mechanisms underlying the role of the androgen/AR and GnRH/GnRH-R axes in CRPC progression and the possible therapeutic implications.
\end{abstract}

Keywords: castration-resistant prostate cancer; androgens; androgen receptors; AR; gonadotropinreleasing hormone; GnRH; gonadotropin-releasing hormone receptors; GnRH-R

\section{Introduction}

Prostate cancer (PCa) still remains the second leading cause of cancer-related deaths in Western countries, although a higher survival rate and a long-term decline in mortality have been recently reported [1]. Most PCas are androgen-dependent in their early stage, and androgen deprivation therapy (ADT), aimed to reduce the circulating levels of testosterone and achieved by chemical castration, still represents the standard care of treatment [2-4]. Gonadotropin-releasing hormone (GnRH) analogs (agonists and antagonists), responsible for the suppression of testicular androgen production, are often associated with inhibitors of androgen receptor (AR) activity to obtain a maximal androgen deprivation condition (combined androgen blockade, CAB) [5,6]. Unfortunately, within 2-3 years, most patients progress towards the so called castration-resistant prostate cancer (CRPC) stage, characterized by tumor growth, even in the presence of castration levels of circulating androgens $[7,8]$.

It is now well established that the androgen/androgen receptor (AR) axis remains a key player in the growth of CRPC [9-13]. Moreover, not only steroids but also peptide hormones and their receptors are deeply involved in the process of PCa progression. Gonadotropin-releasing hormone $(\mathrm{GnRH})$ is the hypothalamic decapeptide known to be a key player in the functions of the pituitary gonadal axis through the activation of its pituitary receptor (GnRH-R) [14-19]. GnRH and GnRH-Rs are also expressed in different 
cancer cells and tissues, including PCa, both androgen-dependent and castration-resistant; the activation of these receptors is associated with a significant antitumor activity [20-34].

\section{The Androgen/AR Axis in CRPC}

Second-line antiandrogen therapy is indicated for the treatment of CRPC patients, supporting the idea that the androgen/AR axis is still active in this progression phase of the tumor [35-41]. To date, several mechanisms involving a persistent activity of the androgen/AR axis in CRPC have been elucidated [12,13,42-44].

\subsection{Intratumoral Synthesis of Androgens}

About two decades ago, it was reported that, after ADT therapy, intratumoral levels of androgens remain high in spite of serum castration levels of testosterone [45]. This observation suggested that circulating adrenal androgens might be uptaken by CRPC cells to be converted to testosterone and dihydrotestosterone (DHT). Subsequently, it was demonstrated that CRPC tissues overexpress both $3 \beta-\mathrm{HSD}$, the enzyme responsible for the conversion of the adrenal steroid dehydroepiandrosterone (DHEA) to androstenedione, and AKR1C3 (17 $\beta-H S D)$, the enzyme involved in the conversion of androstenedione to testosterone and DHT and, therefore, to active androgens [46-48]. Transcription factors regulating the expression of genes involved in androgen biosynthesis are also expressed in CRPC cells [49].

It has also been suggested that, in CRPC tissues, androgens can be synthesized from cholesterol; however, this issue is still a matter of debate $[48,50]$. CYP17A1, the enzyme involved in the synthesis of DHEA and androstenedione, is expressed not only in the adrenal gland but also in PCa tissue [47,50]; treatment options for CRPC patients presently include abiraterone, a specific inhibitor of CYP17A1 activity [51-53].

\subsection{Androgen Receptor Amplification}

CRPC tissues (about 80\%) from patients who progressed after ADT express high levels of AR; $30-50 \%$ of these tissues were reported to carry AR amplification, due to the presence of a high $A R$ gene copy number [54-56]. AR amplification was also detected in circulating tumor cells (CTCs) from patients with metastatic PCa [57]. The overexpressed receptor is sensitive to low levels of androgens, thus allowing PCa cells to progress towards the CRPC stage. Interestingly, AR amplification has been found to be more common in enzalutamide than in abiraterone-resistant patients $[58,59]$.

\subsection{Androgen Receptor Mutations}

The $A R$ gene, belonging to the steroid hormone receptor superfamily, composed of eight exons, is mapped on chromosome Xp11-12 and encodes a $110 \mathrm{kDa}$ (920 amino acids) protein. The full-length AR protein consists of three domains: the $\mathrm{NH}_{2}$-terminal transactivation domain (NTD, encoded by exon 1), the central and conserved DNA-binding domain (DBD, encoded by exons 2 and 3), a flexible hinge region containing a nuclear localization signal and the $\mathrm{COOH}$-terminal ligand-binding domain (LBD, encoded by exons 4-8). The NTD domain contains two trinucleotide repeats that encode polyglutamine and polyglycine tracts. The interaction between NTD and LBD is necessary for the receptor transcriptional activity. In the absence of androgens, the AR is located in the cytoplasm, where it is present in an inactive conformation associated with heat shock proteins. Once bound by androgens (testosterone, DHT), the receptor translocates into the nucleus, where it is activated through dimerization, recruitments of coregulatory/epigenetic factors and stimulation of specific target genes [12,13,43,60-62].

Gain-of-function mutations of the AR are quite frequent (about 50\%) in CRPC patients after antiandrogen therapy; these are usually single point mutations occurring mostly in the LBD of the receptor $[63,64]$. The T878A mutation, with alanine being substituted by threonine, was shown to confer resistance to both first- and second-generation antiandrogens (enzalutamide, apalutamide, darolutamide); similar observations were reported 
for the H875Y, W742C and F876L mutations [58,65-69]. Interestingly, by binding to these mutant receptors, antiandrogens can induce their activation, thus behaving as AR agonists; moreover, these mutations were also shown to be activated by different steroids, such as adrenal androgens, progesterone and estrogens [70-72]. Consequently, AR mutations are responsible for the continuous activation of the receptor even in the presence of low circulating androgen levels after ADT therapy, thus playing a key role in tumor progression. Some gain of function mutations were shown to favor the recruitment of coregulators to the promoter region of AR target genes, thus increasing the transcriptional activity of this receptor $[73,74]$.

Recently, mutant $A R$ receptor genes were reported to be easily detectable in cell-free DNA (cfDNA) obtained from CRPC patients. These data strongly support that the presence of specific circulating mutant ARs can represent a useful biomarker in terms of personalized therapy in CRPC [58,75-77].

The most frequent mutations of the AR in CRPC patient tissues and plasma (cfDNA) are reported in Figure 1.

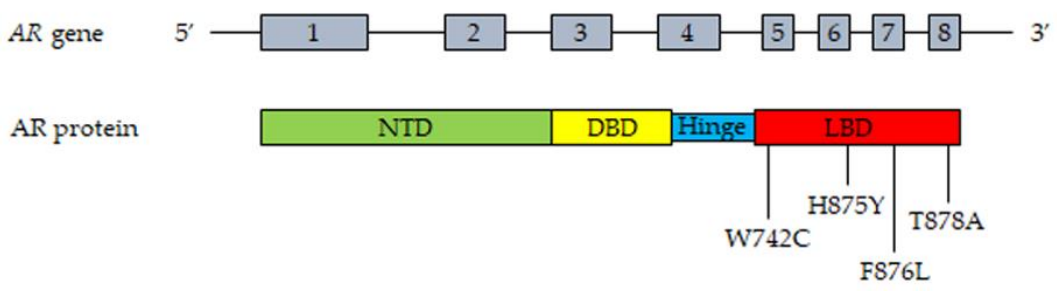

Figure 1. Most frequent mutations of AR detected in tissues and plasma cfDNA from CRPC patients. Upper part, representation of the $A R$ gene structure. Lower part, representation of the AR protein structure with the most frequently mutated amino acids. T878A, alanine substituted by threonine; H875Y, tyrosine substituted by histidine; W742C, cysteine substituted by triptophan; F876L, leucine substituted by phenylalanine. Abbreviations: $\mathrm{AR}$, androgen receptor; $\mathrm{NTD}, \mathrm{NH}_{2}$-terminal transactivation domain; DBD, DNA-binding domain; LBD, ligand-binding domain.

\subsection{Androgen Receptor Splice Variants}

During the last two decades, it has become increasingly clear that, in PCa cells, the $A R$ gene can undergo alternative splicing, giving rise to different splice variants (ARVs) [78-82]. Most of these variants lack the LBD but maintain the ability to enter the nucleus and to bind specific DNA response elements in a ligand-independent manner. Specifically, AR-V7 is truncated at the end of exon 3, but it has been demonstrated to be localized at the nuclear level and to retain constitutive transcriptional activity in the absence of the ligand [83]. The expression of AR-V7 was found to be associated with the development of drug resistance (enzalutamide, abiraterone) and aggressive behavior in CRPC cells [84]. In nude mice harboring human CRPC cell xenografts, treatment with abiraterone significantly increased AR-V7 expression while AR-V7 overexpression promoted tumor growth and invasiveness $[85,86]$; in line with this observation, targeting this receptor variant was reported to suppress tumor growth and to confer sensitivity to antiandrogens (enzalutamide) [87]. In humans, the expression of AR-V7 was observed in tumor biopsies from CRPC patients and significantly correlated with tumor progression and short survival [88-92]. High levels of AR-V7 could also be detected in extracellular vesicles purified from the plasma of CRPC patients, as well as in circulating tumor cells (CTCs) from enzalutamide- or abiraterone-resistant patients, and were found to be associated with a poor prognosis [93-97].

Additional transcript variants are generated by alternative splicing of the $A R$ gene in CRPC $[13,98,99]$. In particular, the ARv567es splice variant originates from the loss of exons 5-7, encoding the LBD, but it conserves the hinge region of exon 4 involved in the nuclear localization of the receptor isoform, thus supporting its constitutive activity irrespective of the presence of the ligand; its expression was shown to increase in tissue 
biopsies after ADT therapy, and to correlate with outcomes to taxane therapy in CTCs, in PCa patients $[88,100,101]$.

Mechanistically, the AR-Vs can form homodimers or heterodimers (by combining with other variants), or they can dimerize with the full-length AR. At the nuclear level, the dimers bind to response elements in the promoter region of specific downstream genes (either unique or canonical AR-regulated genes), thus modulating their expression and promoting the development of CRPC [13,42,89,91,102].

Based on these observations, targeting the AR-Vs and their signaling pathways might represent a novel and effective therapeutic strategy for the treatment of CRPC patients.

\subsection{Androgen Receptor: Transcription Factors and Coregulators}

AR-mediated gene transcription requires the interaction of the receptor with different coregulators (such as the Steroid Receptor Coactivators, SRCs) and transcription factors (such as GATA2 and FOXA1) [103-106].

The transcriptional activity of AR requires the recruitment and cooperation of transcription factors. Among these, the GATA family of transcription factors, consisting of six members, was reported to be involved in the AR-mediated signaling in CRPC cells $[42,43,106]$. In particular, GATA2 pioneer transcription factors were shown to be involved in the androgen-related regulation of PSA expression in CRPC cells; moreover, GATA protein consensus DNA sequences were observed in the AR binding regions of androgen-regulated genes in these cells, supporting their cooperation with the receptor in mediating androgen effects $[106,107]$. This factor was also demonstrated to be a key regulator of the transcriptional activity of AR-Vs in CRPC cells [43].

FOXA-1 (forkhead box A1) is another pioneer transcription factor involved in ARpromoted gene transcription. It was demonstrated to play a key role in AR-mediated tumor growth and progression in CRPC cells [108]. Mechanistically, FOXA1 binds to $\mathrm{AR}$ and the transcription factor HOXB13 at the cytoplasmic level; then, the FOXA1-ARHOXB13 complex translocates into the nucleus where it binds, with the cooperation of GATA2, to specific DNA sequences. FOXA1, HOXB13 and GATA2 open compacted chromatin, increasing the accessibility of these DNA regions to additional transcription factors, thus promoting AR transcriptional activity and the expression of AR-regulated genes [42,108-110].

Coregulators modulate the activity of several proteins in the transcription complex through chemical modifications and are also involved in the recruitment of general transcription factors associated with RNA polymerase II to the constitutive promoter of target genes [106,111]. Specifically, the p160 steroid receptor coactivators (SRC-1, SRC-2 and SRC-3) promote the formation of a complex between AR enhancer sequences and the promoter region of androgen target genes, thus favoring AR transcriptional activity [112]. SRCs expression was found to positively correlate with PCa progression and recurrence [113-115]. Importantly, in PCa cells, SRC-2 was reported to interact with AR at the nuclear level to increase the sensitivity of cancer cells to androgens and to enhance the ligand-independent transcription of AR target genes [116,117]. Similarly, the AR coactivator MAGE-11 (melanoma antigen gene protein-A11) was shown to be overexpressed in CRPC cells as a consequence of the hypomethylation of CpG islands in its promoter region, providing an additional mechanism for the increased AR signaling in CRPC [118].

Taken together, these observations support the notion that the interaction of AR with specific transcription factors and coregulators plays a key role in promoting PCa growth and progression. These mechanisms are presently considered a possible molecular target for novel therapeutic approaches for CRPC.

The most relevant molecular mechanisms underlying the persistent activity of the androgen/AR axis in CRPC cells are summarized in Figure 2. 


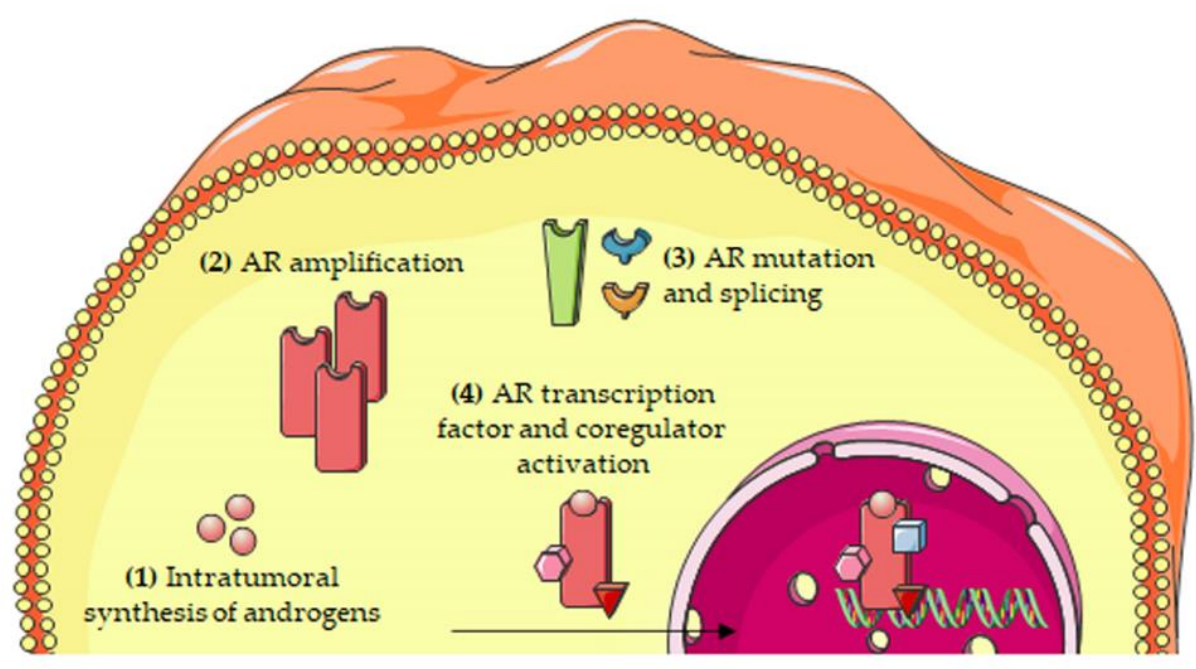

Figure 2. Molecular mechanisms involved in the persistent activity of the androgen/AR axis in CRPC cells. The persistent activation of the androgen/AR axis has been attributed to several mechanisms, including: (1) intratumoral synthesis of androgens; (2) AR amplification; (3) AR mutations and alternative splicing; and (4) increased expression/activity of transcription factors and coregulators of the AR. Abbreviations: AR, androgen receptor.

\section{The GnRH/GnRH-R Axis in CRPC}

GnRH agonists (goserelin, triptorelin, histrelin, leuprolide) bind to pituitary GnRH-Rs and, after an initial stimulation (the so called flare event), induce their down-regulation and desensitization leading to the suppression of gonadotropins (LH and FSH), and subsequently, of testosterone secretion $[119,120]$. To avoid the flare effect, as well as the GnRH-associated side effects (metabolic dysfunction and cardiovascular diseases), GnRH antagonists (cetrorelix, degarelix, abarelix, ozarelix, ganirelix, relugolix) were developed. These compounds act by competitively binding to the pituitary GnRH-Rs, thus immediately suppressing LH and FSH secretion; they were also reported to decrease FSH release for a longer time period and to lower levels than GnRH agonists [121]. Thus, GnRH agonists and antagonists still represent the standard ADT therapy for patients with metastatic PCa [122-124].

In the last three decades, it has been widely demonstrated that GnRH and GnRH-Rs are expressed also in tumor tissues, including PCa and, specifically, CRPC [21,23-26,28,29,32,33,125-127]. This intratumor GnRH-GnRH-R axis is associated with a significant anticancer activity, supporting the notion that it may represent an effective target for novel anticancer strategies.

\subsection{Gonadotropin-Releasing Hormone}

Hypothalamic GnRH (pGlu ${ }^{1}-\mathrm{His}^{2}-\mathrm{Trp}^{3}-\mathrm{Ser}^{4}-\mathrm{Tyr}^{5}-\mathrm{Gly}^{6}-\mathrm{Leu}^{7}-\mathrm{Arg}^{8}-\mathrm{Pro}^{9}-\mathrm{Gly}^{10}-\mathrm{NH}_{2}$ ) is a decapeptide synthesized in a small number of neurons and released in a pulsatile way into the portal blood vessels, through which it reaches the gonadotrope cells at the pituitary level. Here, it binds to its specific receptors, GnRH-Rs, to stimulate gonadotropin secretion and, consequently, gonadal androgen production [14,15]. The N-terminal (Glp-His-Trp-Ser) and the C-terminal (Pro-Gly- $\mathrm{NH}_{2}$ ) domains of the decapeptide are essential for its binding to GnRH-Rs.

In addition to the classical form of GnRH (also called GnRH-I), other forms of the peptide have been identified. The isoform II (GnRH-II) has been observed in most vertebrates [128]. It is a decapeptide whose amino acid sequence differs from that of GnRH in the positions 5,7 and $8\left(\mathrm{His}^{5}, \operatorname{Trp}^{7}, \mathrm{Tyr}^{8}\right)$, known to be involved in the biological functions of the neurohormone. On the other hand, GnRH-II conserves the amino acid sequence of $\mathrm{GnRH}$ in both the $\mathrm{N}$ - and C-terminal domains, supporting that it may recognize, bind and activate the same receptors. The presence of a receptor specific for GnRH-II in vertebrates is still a controversial issue [18,19,128-134]. A third form of GnRH, GnRH-III, was 
identified in sea lamprey (Petromyzon marinus); its structure differs from that of GnRH in amino acids $5-8\left(\mathrm{His}^{5}, \mathrm{Asp}^{6}, \operatorname{Trp}^{7}, \mathrm{Lys}^{8}\right)$; this isoform was shown to possess a very low gonadotropin-releasing effect in vertebrates $[19,135,136]$.

GnRH was reported to be expressed in different types of cancer cells. Specifically, GnRH mRNA expression and immunoreactivity were identified in breast, ovarian, endometrial as well as in PCa cells, both androgen-dependent and castration-resistant. In tumor cells, including CRPC cells, this peptide was shown to be endowed with a significant antiproliferative/proapoptotic biological activity [137-141].

\subsection{Gonadotropin-Releasing Hormone Receptors: Molecular Structure}

The molecular structure of the pituitary GnRH-R, belonging to the GPCR (G protein coupled receptor) receptor family, was identified by Kakar et al., in 1992 [142]. Its gene is located on chromosome 4q13.2 and encodes for a 328 amino acid protein consisting of an extracellular $\mathrm{N}$-terminal domain, a seven helical transmembrane-spanning domain and a uniquely short (1-2 amino acids) intracellular C-terminal domain [133,143-145]. This last domain is responsible for its desensitization triggered by GnRH agonists [146].

Endogenous GnRH, as well as its synthetic agonists, by binding to this receptor, triggers the recruitment/activation of the $\mathrm{G} \alpha \mathrm{q} / 11$ subunit of the $\mathrm{G}$ protein complex, thus activating the downstream effector phospholipase $C \beta$ (PLC $\beta)$. PLC $\beta$, in turn, catalyzes the hydrolysis of phosphatidylinositol 4,5-biphosphate $\left(\mathrm{PIP}_{2}\right)$ into the two second messengers, inositol 1,4,5-triphosphate $\left(\mathrm{IP}_{3}\right)$ and diacylglycerol (DG), leading to protein kinase $\mathrm{C}$ (PKC) activation and increased cytoplasmic levels of $\mathrm{Ca}^{2+}$, respectively. Both PKC and $\mathrm{Ca}^{2+}$ trigger specific downstream signaling pathways involving proteins of the MAPK cascade (ERK1/2, JNK, p38MAPK), finally mediating the biological activity of the receptor ligands, i.e., expression and secretion of the two gonadotropins [27,147-151].

As discussed above, it is now well established that GnRH-Rs are expressed also in different tumor cells and tissues, including PCa, and specifically CRPC [20-26,28-34,152].

The binding affinity of GnRH analogs for these receptors was first investigated, leading to contrasting results. Two classes of GnRH-binding sites, one with low affinity and one with high affinity, were found in human PCa cells, as well as in the Dunning R3327 prostatic adenocarcinoma in rats $[153,154]$. On the other hand, in our laboratory, we could observe the presence of one single class of low affinity GnRH-binding sites in PCa cells, both androgen-dependent and castration-resistant [139,155], while the presence of a single class of high affinity GnRH-binding sites was reported in PC3 CRPC cells and in Dunning R3327 prostatic tumor tissue [156,157].

At the molecular level, we demonstrated that a GnRH-R, with the same mRNA and protein size with the gonadotrope receptors, is expressed in human androgen-dependent and CRPC cells $[21,137,158,159]$; these observations were further confirmed by studies performed in rat Dunning R3327 prostatic adenocarcinoma and in human PCa cells and tissue biopsies [160-163].

The presence of a specific receptor for GnRH-II (GnRH-II-R) in human tissues has been widely investigated; however, this receptor still must be cloned and sequenced. It has been proposed that the GnRH-II-R might correspond to a five transmembrane domain protein, which lacks the transmembrane regions 1 and 2 [132]. Another variant form of this receptor was also reported to be expressed in human tissues and suggested to be nonfunctional due to the presence of a frameshift in exon 1 and a stop codon in exon 2 [164]; on the other hand, this receptor variant was reported to be present in sperm and testis and to be endowed with a functional role in spermatogenesis [165].

The presence of the GnRH-II-R was also investigated in human cancers. Emons and coworkers reported the presence of a functional GnRH-II-R in tumors of the female reproductive system (ovary, endometrium) $[29,32,33,166]$. On the other hand, we demonstrated that, in CRPC cells, the antiproliferative activity of GnRH-II is mediated by the classical form of the GnRH-R [167]; similar observations were reported by Kim and collabora- 
tors [168]. Taken together, these observations support the claim that the presence of a functional GnRH-II-R in human tumor tissues is still a controversial issue.

\subsection{Gonadotropin-Releasing Hormone Receptors: Antiproliferative Activity}

The activation of locally expressed GnRH-Rs, by means of GnRH agonists, was widely reported to induce antitumor/proapoptotic effects in PCa cells. Specifically, we demonstrated that GnRH agonists, significantly and dose-dependently, reduce the proliferation of both androgen-dependent (LNCaP) and castration-resistant (PC3, DU145) human PCa cells, both in vitro and in vivo $[21-23,139,155,169,170]$. GnRH agonists were also shown to suppress the growth of the rat Dunning R-3327 model of PCa as well as of primary human PCa cell cultures $[156,171]$. This activity was found to be mediated by the induction of G2/M phase cell cycle arrest [172,173]. These experimental data are supported by the observation that, in CRPC patients, GnRH agonist-based therapy is associated with a longer disease-specific survival in the presence of a high expression of GnRHRs [174].

GnRH-R activation was further reported to be associated with proapoptotic effects $[175,176]$. In particular, in CRPC cells, GnRH agonists were shown to trigger apoptosis-related molecular events through the down-regulation of the PI3K/AKT signaling pathway, leading to the activation of the downstream JNK kinase, and MEK/ERK kinase activity [177,178]. In our laboratory, we found that GnRH agonists can sensitize, and resensitize, CRPC cells to the proapoptotic activity of the chemotherapeutic agent docetaxel [179]. In line with these observations, cleaved caspase- 8 and -3 , but not -9 , and increased expression and phosphorylation of p53, were reported to increase in primary cell cultures from human PCa samples, supporting the idea that the extrinsic (but not intrinsic) apoptosis pathway is involved in the antitumor activity of GnRH agonists [171,173,180,181]. The different cell context-dependent biological effects of GnRH agonists at the pituitary vs. PCa cell level was suggested to be related to a transient vs. sustained activation of the intracellular signaling pathway (PKC/MAPK) in gonadotropes vs. cancer cells [176,182].

It is now well known that GnRH-R activation interferes with the protumor activity of growth factors and their locally expressed receptors in cancer, and, specifically, in PCa cells [21-24,29,158,183,184].

The insulin-like growth factor (IGF) signaling axis, composed of two receptors (IGF-IR and IGF-IIR) and their specific ligands (IGF-I and IGF-II), was widely shown to be upregulated in PCa cells and tissues [185-187] and is now considered an effective molecular target for PCa therapy [188-190]. We reported that, in CRPC cells, GnRH agonists interfere with the protumoral activity of IGF-I, by reducing IGF-IR expression and activation (i.e., tyrosine phosphorylation) $[21,159]$. Ahearn and coworkers observed that IGF-IR expression positively correlates with tumor stage in human PCa biopsies [191]; a positive correlation was also observed between the expression of IGF-II and the histologic differentiation and pathologic stage, lymph node metastasis and serum PSA (prostate-specific antigen) levels in hormone-treated PCa patients [192].

The EGF/EGF-R (epidermal growth factor and its receptor) signaling pathway is also deeply involved in PCa growth and progression [184,193-195]. We demonstrated that GnRH agonists abrogate the stimulatory effects of EGF on CRPC cell proliferation, in vitro and in vivo, by reducing the expression of EGF-Rs and its downstream transcription factor c-fos [196]. In line with these data, GnRH agonists were found to interfere with the mitogenic activity of EGF and its intracellular signaling pathways in androgen-dependent as well as in CRPC cells [197-199].

Based on the undesired initial flare effect triggered by GnRH agonists, GnRH antagonists, able to compete with the binding of the endogenous decapeptide to its pituitary receptors, were subsequently developed, and it was expected that these compounds might act as GnRH-R antagonists also in tumors. Surprisingly, it was widely demonstrated that GnRH antagonists act as agonists in cancer cells, including PCa cells, exerting a significant antiproliferative/proapoptotic activity both in vitro and in vivo [24-26,29,200-202]. In line with these observations, Castellon and coworkers reported that the GnRH antagonist 
cetrorelix induces an antiproliferative and proapoptotic effect in primary cell cultures from human prostate carcinoma [171]. Sakai et al. analyzed the effects of the GnRH antagonist degarelix on the growth of androgen-dependent and CRPC cells, as well as on VCaP cells derived from a patient with hormone-refractory PCa. They found that degarelix reduces cell viability by triggering apoptosis, both extrinsic and intrinsic, as indicated by increased caspase 3/7, 8 and 9 levels [203]. Interestingly, Cucchiara and coworkers recently reported that degarelix significantly decreases the proliferation of C4-2B MDVR (enzalutamide resistant, expressing high levels of the AR splice variant AR-V7, after a long exposure to the AR antagonist) PCa cells. This antitumor activity was found to be related to a decreased expression of the AR variant, both at the mRNA and at the protein level [204]. Since the GnRH antagonist had a greater impact on protein than on mRNA levels, the authors suggested that this compound might act by triggering a protein degradation through the ubiquitin proteasome system [204-206]. Different molecules such as ASF/SF, JMJD1A, U2AF65, hnRNPA1 and HoxB13 were demonstrated to be involved in AR splicing mechanisms; however, whether degarelix might affect their activity still remains to be investigated [207-210].

To explain the agonistic behavior of GnRH antagonists at the level of tumor cells, Millar and coworkers proposed that these receptors may adopt different conformations according to the cell context in which they are expressed, thus selectively binding to the different GnRH analogs (the "ligand-induce selective signaling" theory) [211].

In addition to the classical form of GnRH, its GnRH-II isoform has also been reported to be expressed in tumors, including PCa [21,29,31,212]. Similar to GnRH, GnRH-II was found to be endowed with a significant antiproliferative/proapoptotic activity in both androgen-dependent and CRPC cells [21,212,213]. Interestingly, the classical form of the GnRH-R was demonstrated to mediate the antitumor effects of GnRH-II in these cells [167].

\subsection{Gonadotropin-Releasing Hormone Receptors: Antimetastatic and Antiangiogenic Activity}

CRPC is frequently associated with the development of metastasis, specifically at the bone, lymph node and visceral level; a better understanding of the molecular mechanisms involved in the metastatic events associated with PCa progression might help identify novel biomarkers and possible targets to increase the therapeutic approaches against this almost untreatable disease [12,214-217].

A remodeling of the intracellular cytoskeleton as well as of the extracellular matrix is deeply involved in the motility and invasive behavior of cancer cells associated with the tumor metastatic spread. We demonstrated that, in CRPC cells, GnRH-R activation significantly reduces both cell migratory and invasive behavior. Moreover, $\mathrm{GnRH}$ agonists interfere with the prometastatic activity of IGF-I by affecting cell morphology, cytoskeleton organization and the expression of the $\alpha \mathrm{v} \beta 3$ integrin, involved in the cell to extracellular matrix adhesion in PCa tissues [218].

In line with these data, it was demonstrated that not only GnRH but also the GnRH-II isoform inhibits CRPC cell motility through the remodeling of actin cytoskeleton [219].

Dondi and coworkers reported that, in DU145 and PC3 CRPC cells, GnRH analogs inhibit the activity of the plasminogen activator (PA) system, implicated in the local degradation of the extracellular matrix. Specifically, they showed that both the GnRH agonist leuprolide and the antagonist cetrorelix decrease cell motility and invasiveness by reducing the enzymatic activity and the secretion of uPA (urokinase-type PA), while increasing the expression of the PA inhibitor PAI-1 [220]. In line with these data, cetrorelix was reported to suppress DU145 cell invasiveness by decreasing the expression of proteins involved in cell-to-cell adhesion molecules (i.e., E-cadherin, $\alpha$ - and $\beta$-catenin) [221].

It is well known that metastasis is a complex process that involves the cooperative actions of different cancer cell subpopulations, in which cancer stem cells would be responsible for the final step of colonizing premetastatic niches. Cancer stem cells are also deeply involved in the mechanisms of drug resistance, being able to avoid the effects of standard antitumor therapies [222]. Recently, Contreras and coworkers isolated and characterized a 
cell subpopulation with stem-like properties from explants of human prostate tumors and found that these cells do not express the GnRH-R [34,223].

Angiogenesis is the process by which new vascular vessels form from the pre-existing vasculature. In tumors, the formation of new blood vessels is necessary to provide an appropriate blood supply to support cell viability and proliferation. Hence, this process plays a key role in tumor progression and is now recognized as one of the hallmarks of cancer [224,225]. Vascular endothelial growth factor (VEGF) is an essential factor for vascular endothelial cells; its expression is up-regulated in most cancers, and its crucial role in tumor angiogenesis is well defined [226-231]. Among the VEGF isoforms, VEGF-A was shown to play a key role in PCa angiogenesis [232-234]. VEGF-A is overexpressed in $\mathrm{PCa}$, and high levels of this growth factor are associated with the presence of metastasis and a poorer prognosis $[235,236]$. Furthermore, in PCa, a high expression of VEGF-A was observed not only in endothelial cells, but also in tumor cells [235].

In our laboratory, we observed that GnRH-Rs are expressed in HUVEC (human umbilical vein endothelial) cells; GnRH agonists reduce HUVEC cell proliferation and counteract the effects of VEGF-A on their ability to form capillary-like tubes [237]. Recently, a bifunctional fusion protein (LMRAP), consisting of a GnRH Fc fragment and an integrin targeting peptide, was developed as a new strategy for the therapy of GnRH-R expressing tumors. The antitumor activity of this protein was assessed in different cancer cells lines, including CRPC cells, in vitro and in vivo. It was reported that this protein significantly inhibits tumor growth and angiogenesis [238].

\subsection{Gonadotropin-Releasing Hormone Receptors: Signal Transduction}

The inhibitory effects of GnRH-R activation on tumor growth and progression suggested that, in cancer cells, these receptors might be coupled with intracellular signaling mechanisms different from those found at the pituitary level. It is now well accepted that, while GnRH-Rs expressed on the gonadotrope cell membranes are associated with the G $\alpha \mathrm{q} / \mathrm{PLC} / \mathrm{PKC}$ signaling pathway, in cancer cells, these receptors are mainly coupled with the G $\alpha \mathrm{i} / \mathrm{cAMP} / \mathrm{PKA}$ cascade of transduction mechanisms [21,29,31,148,211,239,240].

We demonstrated that, in PCa and, specifically, CRPC cells, GnRH-R activation significantly interferes with the forskolin-induced increase in cytoplasmic cAMP levels while pertussis toxin counteracts the antiproliferative effects of GnRH analogs [152], suggesting that the G $\alpha$ i signaling pathway is involved in the anticancer activity of these compounds. In these cells, by decreasing cAMP levels, GnRH-R ligands trigger the activation of a PTP (phosphotyrosine phosphatase), an enzyme responsible for the dephosphorylation (i.e., inactivation) of growth factor receptors. It is well established that GnRH ligands prevent the activity of growth factors, such as EGF and IGF-I, thus leading to the suppression of the expression/activity of their intracellular signaling mediators (i.e., ERK1/2, PI3K/AKT and $c-f o s)$ and, consequently, of their protumoral effects $[196,218,239]$. In human benign prostatic hyperplasia (BPH-1) cells, GnRH-R ligands (agonists and antagonists) stimulate the G $\alpha$ i-mediated activation of the p38MAPK and JNK kinases [240]. The JNK/Jun signaling pathway, triggered by AKT inhibition and subsequent stabilization/activation of its upstream regulator MLK3 (mixed-lineage kinase 3), was also shown to be involved in the anticancer activity of GnRH analogs in PCa cells $[28,177]$. Similar observations were reported in cancer cells of the female reproductive system $[29,241,242]$.

Naor's laboratory widely demonstrated that the G $\alpha$ q/PLC/PKC pathway is also involved in the antiproliferative/proapoptotic activity of GnRH analogs in cancer cells [243]. It was found that different PKC isoforms (PKC $\alpha, P K C \beta I I$ and $P K C \varepsilon)$ are present in gonadotropes as well as in PCa cells, despite being at a different level of expression. Moreover, in CRPC cells, GnRH agonists induce a sustained activation of the PKC/MAPK (p38MAPK and JNK) signaling cascade [182]. In particular, a c-Src-mediated signal and a reduction of AKT activity were found to be involved in the activation of the MLK3/JNK axis [176]. 
Taken together, these data strongly support the notion that different GnRH-R-associated signaling pathways are involved in the opposite effects of GnRH analogs in pituitary vs. CRPC cells.

The main signaling pathways associated with the GnRH/GnRH-R axis in CRPC cells are summarized in Figure 3.

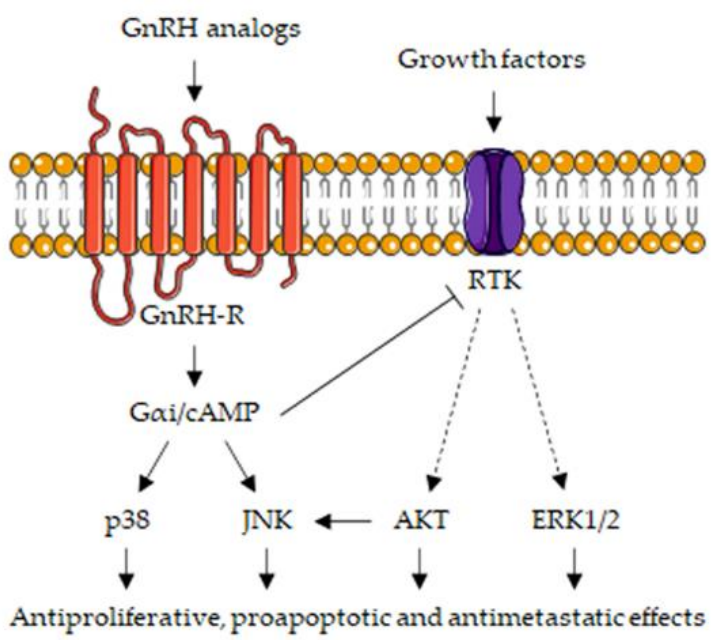

Figure 3. Intracellular signaling pathways involved in the antitumor activity of the GnRH-R in CRPC cells. The binding of GnRH analogs (both agonists and antagonists) to locally expressed GnRH-Rs triggers the activation of the G $\alpha \mathrm{i} / \mathrm{cAMP}$ pathway. By decreasing cAMP levels, GnRH-R ligands activate the MAPK kinase cascades (i.e., p38MAPK and JNK), deeply involved in their anticancer effects. GnRH-R analogs also trigger the activation of a PTP, an enzyme responsible for the dephosphorylation (i.e., inactivation) of growth factor receptors (RTK), thus leading to the suppression of the expression/activity of their intracellular signaling mediators (i.e., ERK1/2 and AKT). In addition, AKT inhibition also leads to the stimulation of the JNK signaling pathway, further potentiating its antitumor activity. Abbreviations: cAMP, cyclic adenosine monophosphate; p38, p38 mitogen-activated protein kinase; JNK, c-Jun N-terminal kinase; RTK, receptor tyrosine kinase; AKT, protein kinase B; ERK1/2, extracellular signal-regulated kinase 1/2.

\section{Androgen and Gonadotropin-Releasing Hormone Receptors: Molecular Targets for Therapeutic Strategies in CRPC}

ADT, based on GnRH agonists or antagonists, still remains the mainstay treatment of hormone-dependent PCa. Results from different clinical trials also support the use of AR antagonists, such as enzalutamide and apalutamide, as well as of androgen synthesis inhibitors, such as abiraterone, for the treatment of hormone-sensitive PCa [4,244-251]. Unfortunately, in a few years, the majority of patients progress towards the CRPC stage, with tumor growing even in the presence of castration levels of circulating androgens.

Taxane-based cytotoxic chemotherapy, i.e., docetaxel, is considered a therapy of choice for CRPC patients; cabazitaxel was also introduced in the clinical settings; however, its efficacy was found to be lower than that of docetaxel in a phase III clinical trial (FIRSTANA) [252]. Immunotherapy, such as sipuleucel-T or immune checkpoint inhibitors (nivolumab and pembrolizumab, binding and inactivating the T cell antigen PD1; durvalumab, targeting PD-L1), is another therapeutic strategy for CRPC patients. Unfortunately, serious side effects and a lower efficacy than expected are commonly associated with chemotherapy and immunotherapy, respectively [253-257].

Given the persisting role of the AR in the progression of PCa to the CRPC stage, inhibitors of the androgen pathways are commonly used for the treatment of CRPC patients [38,254,255,257,258]. Second-generation non-steroidal AR antagonists (enzalutamide, apalutamide, darolutamide) compete with androgens by binding to AR receptors and also inhibit AR translocation into the nucleus and its downstream binding to, and activation of, response elements in the promoter region of specific target genes. Enzalutamide was 
reported to significantly reduce PSA levels and the metastasis-free survival while increasing the progression-free survival (PFS) and the overall survival (OS) in non-metastatic and metastatic CRPC patients, either before or after chemotherapy $[247,249,259-262]$. Similar positive clinical outcomes were reported with the more recently developed, secondgeneration AR antagonists such as apalutamide and darolutamide [37,263-265]. Abiraterone, the inhibitor of CYP17A1 activity and, therefore, of androgen biosynthesis, demonstrated efficacy (reduction of risk of death, PFS and OS) and safety in metastatic CRPC patients, both in the pre- and post-chemotherapy settings [266-268]. Interestingly, it has been observed that, in a sequential treatment setting, starting therapy with abiraterone and subsequently switching to enzalutamide provides better results (in terms of PFS and PSA-PFS) than those obtained with the opposite sequence $[39,255,257,269]$.

The presence of a GnRH/GnRH-R axis associated with antitumor activities in PCa and specifically in CRPC cells supports the notion that it might be considered an additional direct target of GnRH analog-based (agonists and antagonists) ADT.

Gnanapragasam and coworkers reported that a high expression of GnRH-Rs correlates with a better clinical outcome in CRPC patients treated with GnRH agonists [174]. Moreover, it was shown that, in PCa patients, switching from a GnRH agonist (goserelin or leuprolide) to another agonist (leuprolide or goserelin), after disease progression, is associated with a reduction of PSA levels [270]. Co-treatment of chemotherapy-naïve CRPC patients with a GnRH agonist and docetaxel resulted in an improved PFS with respect to chemotherapy alone [271]. In line with these data, patients developing CRPC often continue on a GnRH agonist-based therapy when starting chemotherapy [272]. However, different results were reported by other clinical trials. In the ICELAND clinical trial, patients with advanced/relapsing PCa were treated with the GnRH agonist leuprorelin, either alone or in combination with bicalutamide. It was observed that continuous androgen deprivation did not improve PSA progression [273].

As discussed above, by binding to GnRH receptors expressed in PCa cells, as specifically in CRPC cells, GnRH antagonists behave as agonists triggering marked antitumor effects. To this purpose, it must be underlined that these compounds elicit a faster suppression of testosterone, as well as of FSH and PSA levels, in PCa patients [124,274]. Abufaraj and coworkers recently reported that, in patients with metastatic $\mathrm{PCa}, \mathrm{GnRH}$ antagonists are associated with lower overall mortality rate (but without a significant difference in PSA progression) and cardiovascular events compared with GnRH agonists, while inducing higher injection site reactions [123]. Degarelix was shown to induce a more rapid decrease in testosterone levels and a better PSA control with respect to leuprolide in PCa patients [258,275-277]. Sugimura et al. showed that switching from a GnRH agonist to an antagonist (degarelix) was associated with a delay in tumor progression in a case of CRPC [278]; moreover, a recent systematic meta-analysis has pointed out that treatment with degarelix after failure of a GnRH agonist is associated with decreased or stable PSA levels in patients progressing to the CRPC phase [279]. However, in spite of these data, evidence to make an incontrovertible statement that $\mathrm{GnRH}$ antagonists have a greater efficacy than agonists in PCa treatment is considered still limited [123,280,281].

Recently, cytotoxic GnRH bioconjugates were developed as a new therapeutical approach for tumors expressing GnRH-Rs; these compounds consist of a GnRH-derivative covalently linked to a cytotoxic drug. It is expected that, by binding to its receptor, the GnRH derivative may specifically carry the cytotoxic drug to cancer cells without affecting normal cells. AEZS-108 (also known as AN-152), a bioconjugate consisting of a GnRH derivative covalently linked to doxorubicin via an ester bond, was developed, and its anticancer activity was investigated in different types of tumors [282-284]. This peptide cytotoxin was reported to exert a significant antiproliferative/proapoptotic activity in $\mathrm{PCa}$, and specifically in CRPC cells, in vitro and in preclinical studies [285-287]. Results from phase I and II clinical trials demonstrated that, in chemotherapy naïve and taxane-resistant CRPC patients, AEZS-108 reduces PSA levels and is effective in increasing PFS [288,289]. Promising results were also obtained with different GnRH-based cytotoxic bioconjugates 
in CRPC cells, both in vitro and in vivo [283,290,291]. In our laboratory, we investigated the antitumor activity of bioconjugates consisting of daunorubicin linked to the GnRH-III isoform in CRPC cells. We found that these compounds are rapidly internalized and exert a significant antitumor activity in these cells [292]. Further studies are needed to confirm the efficacy and the lack of toxicity of GnRH-based cytotoxic bioconjugates in PCa.

\section{Conclusions and Future Perspectives}

It is now well established that the progression of PCa towards its most aggressive CRPC phase is characterized by an active hormonal landscape.

Specifically, a persistent activity of the androgen/AR axis has been demonstrated to be present in CRPC cells. This is correlated to different molecular mechanisms, including: intratumoral synthesis of androgens; AR amplification; AR mutations; alternative splicing of the AR mRNA leading to the expression of AR splice variants (i.e., AR-V7 and Arv567es); increased expression/activity of transcription factors and coregulators of the AR. Based on these data, second-generation non-steroidal antiandrogens (enzalutamide, darolutamide, apalutamide) as well as inhibitors of enzymes involved in the androgen biosynthesis (abiraterone, the CYP17A1) are commonly used for the treatment of CRPC patients.

In addition, a GnRH/GnRH-R axis, widely reported to be associated with a substantial antiproliferative/proapoptotic, antimetastatic and antiangiogenic activity, is also expressed in CRPC cells. In line with these data, a high expression of GnRH-R in PCa tissues correlates with a better clinical outcome in CRPC patients. Interestingly, in cancer cells expressing the GnRH receptor, GnRH antagonists trigger the same antitumor activity of GnRH agonists, suggesting that differences in the molecular structure/mechanisms of these receptors might exist at the tumor vs. pituitary level.

In accordance with these observations, ADT interventions, based on a gonadotropinreleasing hormone agonist, with or without an antiandrogen drug (AR antagonist or inhibitor of androgen synthesis), represent a mainstay treatment for PCa, even in the CRPC stage [255,257,258]. Recent clinical trials (PROSPER, SPARTAN, ARAMIS) reported a synergistic positive effect of AR antagonists (enzalutamide, apalutamide, darolutamide) and GnRH analog-based ADT on clinical outcomes (PSA levels and doubling time, median time to metastasis, PFS, OS, risk of death) in non-metastatic CRPC patients [262,293-296]. Results from these trials demonstrate that "initiating therapy at early stage of the disease is more effective than waiting until mCRPC development" [38]. The optimal sequencing and combination of these standard treatment strategies for CRPC patients is still a matter of debate [255,257].

In spite of these promising results, the incidence of PCa is still increasing. Underlying the molecular pathways of PCa development and progression towards the most aggressive, castration-resistant stage is mandatory for the identification of novel molecular markers/targets and therapeutic approaches for CRPC patients.

Assessing the AR status, and, specifically, the AR gene copy number, in plasma DNA is a minimally invasive tool for the identification of the development of resistance in PCa patients escaping enzalutamide- or abiraterone-based therapies. Recently, Beltran and coworkers reported that CRPC patients with high plasma $A R$ copy number do not have a worse response to taxane-based chemotherapy compared with patients with normal plasma $A R$. These authors speculate that the analysis of plasma levels of $A R$ copy number in the different stages of PCa might improve therapy selection for CRPC patients [297].

Several studies are presently ongoing with the aim to solve the issue of the role and subsequent potential targeting of AR mutations in PCa. As discussed in this review, specific AR mutations not only confer resistance to antiandrogens (such as enzalutamide) but can also convert these compounds in AR agonists, indicating a rapid development of drug resistance. In recent papers, by means of molecular docking and molecular dynamics simulations, novel AR antagonists were developed and found to exert a significant antitumor effect in CRPC cells as well as in PCa cells engineered to overexpressed the F876L mutant AR [298,299]. Moreover, a full characterization of AR mutations, achieved by 
genomic studies, will likely increase the treatment options for CRPC patients, in terms of personalized therapy. Recently, mutant $A R$ s were reported to be easily detectable in cfDNA from CRPC patients [58,75-77]. It is now accepted that AR inhibition can be achieved also through its degradation. Selective AR degraders (SARDs) have been recently developed and demonstrated to exert significant antitumor activities in PCa [250,300]. However, further experimental studies as well as clinical trials are needed to confirm the utility of these novel approaches in the clinical setting.

AR-V7 is the most frequent AR splice variant detected in PCa, and, specifically, in CRPC tissues and its levels of expression, appears to be strictly correlated to resistance to enzalutamide and abiraterone. CTCs are now considered a clinically relevant biomarker of disease progression in different pathologies, including PCa. Recently, it has been reported that AR-V7 mRNA expression, assessed via the Adna test platform and the EPIC sciences CTC-based platform (an immunofluorescence-based detection assay that measures the AR variant protein localized in the nucleus), can be detected in the plasma from patients with mCRPC treated with enzalutamide. Compared with AR-V7 negative patients, AR-V7 positive patients treated with enzalutamide showed a shorter PFS and OS [301,302]. Thus, the assessment of the expression of different mutant/variant forms of the AR in CTCs is now considered an effective predictive biomarker of PCa progression and a useful tool for choosing the right therapeutic approach in terms of precision medicine.

Extracellular vesicles (EVs, previously called exosomes) carry different types of bioactive molecules to recipient cells in the tumor microenvironment. EVs mediate intercellular communications, including re-education of stromal cells, modulation of cancer metabolism, and also development drug resistance. The bioactive molecule profiles/signatures of tumor-derived Es change over time, reflecting the real-time status of cancer cells. Specifically, different bioactive molecules have been identified in PCa-derived EVs, such as AR and AR-V7, caveolin-1 (involved in cancer cell stemness), has-miRNA-940 (involved in the osteogenic differentiation of mesenchymal stem cells), integrin $\alpha \mathrm{v} \beta 3$ and $\alpha \mathrm{v} \beta 6$ (involved in PCa cell metastatic behavior), miR-409 (involved in prostate tumorigenesis), TGF $\beta$ (involved in the differentiation of mesenchymal stem cell into pro-invasive and pro-angiogenic myofibroblasts) and MDR-1 (multidrug resistance-1, involved in drug efflux) $[95,303]$. Based on these observations, PCa-derived EVs are now considered valuable diagnostic and prognostic biomarkers in progressing $\mathrm{PCa}$, supporting their potential role in disease management.

As discussed in this review, GnRH receptors, associated with a significant antiproliferative activity, are expressed in PCa, and, specifically, in CRPC cells and tumors. Moreover, GnRH-R expression was also demonstrated in PCa stem cells isolated from explants of human prostate tumors. PCa patients expressing high levels of GnRH receptors, have a better clinical response to the GnRH-analog based therapy. GnRH analogs, either alone or together with AR inhibitors or taxane derivatives, still represent the mainstay therapy for CRPC patients.

Based on this observation, GnRH analog (GnRH, GnRH-II and GnRH-III)-based cytotoxic bioconjugates have been recently developed with the aim to specifically carry the cytotoxic drug (doxorubicin, daunorubicin) to cancer cells expressing the GnRH-R, while sparing normal cells. In particular, the bioconjugate AEZS-108 (AN-152) consists of a GnRH derivative linked to the cytotoxic drug doxorubicin. This compound was found to significantly inhibit the growth of CRPC cells, both in vitro and in vivo. Phase I and II clinical trials showed that AEZS-108 efficiently reduces PSA levels and increases PFS in CRPC patients. Further studies are needed to confirm these as promising.

In conclusion, a deeper clarification of the expression and activities of both the androgen/AR and GnRH/GnRH-R axes in the CRPC stage will likely lead to the identification of novel predictive biomarkers as well as to the improvement of the therapeutical options for this almost untreatable disease, in terms of precision medicine. 
Author Contributions: Literature search, F.F. and P.L.; writing-original draft preparation, P.L.; writing-review and editing, F.F. and P.L.; funding acquisition, F.F. and P.L. All authors have read and agreed to the published version of the manuscript.

Funding: This research was funded by MIUR Progetto di Eccellenza (Department of Pharmacological and Biomolecular Sciences, Università degli Studi di Milano) and PRIN 2015, project n. 2015B7M39T_004 (Patrizia Limonta). F.F. was supported by an AIRC fellowship for Italy.

Data Availability Statement: Not applicable.

Conflicts of Interest: The authors declare no conflict of interest.

\section{References}

1. Siegel, R.L.; Miller, K.D.; Fuchs, H.E.; Jemal, A. Cancer Statistics, 2021. CA Cancer J. Clin. 2021, 71, 7-33. [CrossRef]

2. Labrie, F.; Candas, B.; Gomez, J.L.; Cusan, L. Can combined androgen blockade provide long-term control or possible cure of localized prostate cancer? Urology 2002, 60, 115-119. [CrossRef]

3. Singer, E.A.; Golijanin, D.J.; Miyamoto, H.; Messing, E.M. Androgen deprivation therapy for prostate cancer. Expert Opin. Pharmacother. 2008, 9, 211-228. [CrossRef]

4. Litwin, M.S.; Tan, H.J. The Diagnosis and Treatment of Prostate Cancer: A Review. JAMA 2017, 317, 2532-2542. [CrossRef]

5. Onozawa, M.; Akaza, H.; Hinotsu, S.; Oya, M.; Ogawa, O.; Kitamura, T.; Suzuki, K.; Naito, S.; Namiki, M.; Nishimura, K.; et al. Combined androgen blockade achieved better oncological outcome in androgen deprivation therapy for prostate cancer: Analysis of community-based multi-institutional database across Japan using propensity score matching. Cancer Med. 2018, 7, 4893-4902. [CrossRef]

6. Tamada, S.; Iguchi, T.; Kato, M.; Asakawa, J.; Kita, K.; Yasuda, S.; Yamasaki, T.; Matsuoka, Y.; Yamaguchi, K.; Matsumura, K.; et al. Time to progression to castration-resistant prostate cancer after commencing combined androgen blockade for advanced hormonesensitive prostate cancer. Oncotarget 2018, 9, 36966-36974. [CrossRef]

7. Perner, S.; Cronauer, M.V.; Schrader, A.J.; Klocker, H.; Culig, Z.; Baniahmad, A. Adaptive responses of androgen receptor signaling in castration-resistant prostate cancer. Oncotarget 2015, 6, 35542-35555. [CrossRef]

8. Galletti, G.; Leach, B.I.; Lam, L.; Tagawa, S.T. Mechanisms of resistance to systemic therapy in metastatic castration-resistant prostate cancer. Cancer Treat. Rev. 2017, 57, 16-27. [CrossRef] [PubMed]

9. Nemes, A.; Tomuleasa, C.; Kacso, G. The androgen receptor remains a key player in metastatic hormone-refractory prostate cancer. Implications for new treatments. J. BUON 2014, 19, 357-364. [PubMed]

10. Tilki, D.; Schaeffer, E.M.; Evans, C.P. Understanding Mechanisms of Resistance in Metastatic Castration-resistant Prostate Cancer: The Role of the Androgen Receptor. Eur. Urol. Focus 2016, 2, 499-505. [CrossRef] [PubMed]

11. Fujimura, T.; Takayama, K.; Takahashi, S.; Inoue, S. Estrogen and Androgen Blockade for Advanced Prostate Cancer in the Era of Precision Medicine. Cancers 2018, 10, 29. [CrossRef]

12. Aurilio, G.; Cimadamore, A.; Mazzucchelli, R.; Lopez-Beltran, A.; Verri, E.; Scarpelli, M.; Massari, F.; Cheng, L.; Santoni, M.; Montironi, R. Androgen Receptor Signaling Pathway in Prostate Cancer: From Genetics to Clinical Applications. Cells 2020, 9 , 2653. [CrossRef]

13. Messner, E.A.; Steele, T.M.; Tsamouri, M.M.; Hejazi, N.; Gao, A.C.; Mudryj, M.; Ghosh, P.M. The Androgen Receptor in Prostate Cancer: Effect of Structure, Ligands and Spliced Variants on Therapy. Biomedicines 2020, 8, 422. [CrossRef] [PubMed]

14. Baba, Y.; Matsuo, H.; Schally, A.V. Structure of the porcine LH- and FSH-releasing hormone. II. Confirmation of the proposed structure by conventional sequential analyses. Biochem. Biophys. Res. Commun. 1971, 44, 459-463. [CrossRef]

15. Schally, A.V.; Arimura, A.; Baba, Y.; Nair, R.M.; Matsuo, H.; Redding, T.W.; Debeljuk, L. Isolation and properties of the FSH and LH-releasing hormone. Biochem. Biophys. Res. Commun. 1971, 43, 393-399. [CrossRef]

16. Conn, P.M.; Crowley, W.F., Jr. Gonadotropin-releasing hormone and its analogs. Annu. Rev. Med. 1994, 45, 391-405. [CrossRef]

17. Harrison, G.S.; Wierman, M.E.; Nett, T.M.; Glode, L.M. Gonadotropin-releasing hormone and its receptor in normal and malignant cells. Endocr. Relat. Cancer 2004, 11, 725-748. [CrossRef]

18. Millar, R.P. GnRHs and GnRH receptors. Anim. Reprod. Sci. 2005, 88, 5-28. [CrossRef]

19. Tzoupis, H.; Nteli, A.; Androutsou, M.; Tselios, T. Gonadotropin Releasing Hormone and GnRH Receptor: Structure, Function and Drug Development. Curr. Med. Chem. 2019, 27, 6136. [CrossRef]

20. Limonta, P.; Marelli, M.M.; Moretti, R.M. LHRH analogues as anticancer agents: Pituitary and extrapituitary sites of action. Expert Opin. Investig. Drugs 2001, 10, 709-720. [CrossRef]

21. Limonta, P.; Moretti, R.M.; Montagnani Marelli, M.; Motta, M. The biology of gonadotropin hormone-releasing hormone: Role in the control of tumor growth and progression in humans. Front. Neuroendocrinol. 2003, 24, 279-295. [CrossRef]

22. Moretti, R.M.; Marelli, M.M.; Groeninghen, J.C.v.; Motta, M.; Limonta, P. Inhibitory activity of luteinizing hormone-releasing hormone on tumor growth and progression. Endocr. Relat. Cancer 2003, 10, 161-167. [CrossRef]

23. Marelli, M.M.; Moretti, R.M.; Caulier, J.J.; Motta, M.; Limonta, P. Gonadotropin-Releasing Hormone (GnRH) receptors in tumors: A new rationale for the therapeutical application of GnRH analogs in cancer patients? Curr. Cancer Drug Targets 2006, 6, 257-269. [CrossRef] 
24. Limonta, P.; Marelli, M.M.; Mai, S.; Motta, M.; Martini, L.; Moretti, R.M. GnRH Receptors in Cancer: From Cell Biology to Novel Targeted Therapeutic Strategies. Endocr. Rev. 2012, 33, 784-811. [CrossRef]

25. Limonta, P.; Manea, M. Gonadotropin-releasing hormone receptors as molecular therapeutic targets in prostate cancer: Current options and emerging strategies. Cancer Treat. Rev. 2013, 39, 647. [CrossRef]

26. Manea, M.; Marelli, M.M.; Moretti, R.M.; Maggi, R.; Marzagalli, M.; Limonta, P. Targeting hormonal signaling pathways in castration resistant prostate cancer. Recent Pat. Anticancer Drug Discov. 2014, 9, 267-285. [CrossRef]

27. Limonta, P.; Marelli, M.M.; Moretti, R.; Marzagalli, M.; Fontana, F.; Maggi, R. GnRH in the human female reproductive axis. Vitam. Horm. 2018, 107, 27-66.

28. Aguilar-Rojas, A.; Perez-Solis, M.A.; Maya-Nunez, G. The gonadotropin-releasing hormone system: Perspectives from reproduction to cancer (Review). Int. J. Oncol. 2016, 48, 861-868. [CrossRef]

29. Grundker, C.; Emons, G. The Role of Gonadotropin-Releasing Hormone in Cancer Cell Proliferation and Metastasis. Front. Endocrinol. 2017, 8, 187. [CrossRef]

30. Schally, A.V.; Block, N.L.; Rick, F.G. Discovery of LHRH and development of LHRH analogs for prostate cancer treatment. Prostate 2017, 77, 1036-1054. [CrossRef]

31. Fontana, F.; Marzagalli, M.; Montagnani Marelli, M.; Raimondi, M.; Moretti, R.M.; Limonta, P. Gonadotropin-Releasing Hormone Receptors in Prostate Cancer: Molecular Aspects and Biological Functions. Int. J. Mol. Sci. 2020, 21, 9511. [CrossRef]

32. Emons, G.; Grundker, C. The Role of Gonadotropin-Releasing Hormone (GnRH) in Endometrial Cancer. Cells 2021, 10, 292. [CrossRef]

33. Grundker, C.; Emons, G. Role of Gonadotropin-Releasing Hormone (GnRH) in Ovarian Cancer. Cells 2021, 10, 437. [CrossRef]

34. Contreras, H.R.; Lopez-Moncada, F.; Castellon, E.A. Cancer stem cell and mesenchymal cell cooperative actions in metastasis progression and hormone resistance in prostate cancer: Potential role of androgen and gonadotropinreleasing hormone receptors (Review). Int. J. Oncol. 2020, 56, 1075-1082. [CrossRef]

35. Miyake, H.; Matsushita, Y.; Watanabe, H.; Tamura, K.; Motoyama, D.; Ito, T.; Sugiyama, T.; Otsuka, A. Comparative assessment of prognostic outcomes between first-generation antiandrogens and novel androgen-receptor-axis-targeted agents in patients with non-metastatic castration-resistant prostate cancer. Int. J. Clin. Oncol. 2019, 24, 842-847. [CrossRef]

36. Altavilla, A.; Casadei, C.; Lolli, C.; Menna, C.; Ravaglia, G.; Gurioli, G.; Farolfi, A.; Brighi, N.; Conteduca, V.; Burgio, S.L.; et al. Enzalutamide for the treatment of nonmetastatic castration-resistant prostate cancer. Expert Opin. Pharmacother. 2020, 21, 2091-2099. [CrossRef]

37. Crawford, E.D.; Stanton, W.; Mandair, D. Darolutamide: An Evidenced-Based Review of Its Efficacy and Safety in the Treatment of Prostate Cancer. Cancer Manag. Res. 2020, 12, 5667-5676. [CrossRef]

38. Lavaud, P.; Dumont, C.; Thibault, C.; Albiges, L.; Baciarello, G.; Colomba, E.; Flippot, R.; Fuerea, A.; Loriot, Y.; Fizazi, K. Next-generation androgen receptor inhibitors in non-metastatic castration-resistant prostate cancer. Ther. Adv. Med. Oncol. 2020, 12, 1758835920978134. [CrossRef]

39. Mori, K.; Miura, N.; Mostafaei, H.; Quhal, F.; Sari Motlagh, R.; Pradere, B.; Kimura, S.; Kimura, T.; Egawa, S.; Briganti, A.; et al. Sequential therapy of abiraterone and enzalutamide in castration-resistant prostate cancer: A systematic review and meta-analysis. Prostate Cancer Prostatic Dis. 2020, 23, 539-548. [CrossRef]

40. Pyrgidis, N.; Vakalopoulos, I.; Sountoulides, P. Endocrine consequences of treatment with the new androgen receptor axis-targeted agents for advanced prostate cancer. Hormones 2020, 20, 73. [CrossRef]

41. Cassinello, J.; Dominguez-Lubillo, T.; Gomez-Barrera, M.; Hernando, T.; Parra, R.; Asensio, I.; Casado, M.A.; Moreno, P. Optimal treatment sequencing of abiraterone acetate plus prednisone and enzalutamide in patients with castration-resistant metastatic prostate cancer: A systematic review and meta-analysis. Cancer Treat. Rev. 2021, 93, 102152. [CrossRef] [PubMed]

42. Cai, Z.; Chen, W.; Zhang, J.; Li, H. Androgen receptor: What we know and what we expect in castration-resistant prostate cancer. Int. Urol. Nephrol. 2018, 50, 1753-1764. [CrossRef] [PubMed]

43. Feng, Q.; He, B. Androgen Receptor Signaling in the Development of Castration-Resistant Prostate Cancer. Front. Oncol. 2019, 9 , 858. [CrossRef]

44. Mollica, V.; Di Nunno, V.; Cimadamore, A.; Lopez-Beltran, A.; Cheng, L.; Santoni, M.; Scarpelli, M.; Montironi, R.; Massari, F. Molecular Mechanisms Related to Hormone Inhibition Resistance in Prostate Cancer. Cells 2019, 8, 43. [CrossRef]

45. Titus, M.A.; Schell, M.J.; Lih, F.B.; Tomer, K.B.; Mohler, J.L. Testosterone and dihydrotestosterone tissue levels in recurrent prostate cancer. Clin. Cancer Res. 2005, 11, 4653-4657. [CrossRef]

46. Stanbrough, M.; Bubley, G.J.; Ross, K.; Golub, T.R.; Rubin, M.A.; Penning, T.M.; Febbo, P.G.; Balk, S.P. Increased expression of genes converting adrenal androgens to testosterone in androgen-independent prostate cancer. Cancer Res. 2006, 66, 2815-2825. [CrossRef]

47. Cai, C.; Balk, S.P. Intratumoral androgen biosynthesis in prostate cancer pathogenesis and response to therapy. Endocr. Relat. Cancer 2011, 18, R175-R182. [CrossRef]

48. Kumagai, J.; Hofland, J.; Erkens-Schulze, S.; Dits, N.F.; Steenbergen, J.; Jenster, G.; Homma, Y.; de Jong, F.H.; van Weerden, W.M. Intratumoral conversion of adrenal androgen precursors drives androgen receptor-activated cell growth in prostate cancer more potently than de novo steroidogenesis. Prostate 2013, 73, 1636. [CrossRef] 
49. Montgomery, R.B.; Mostaghel, E.A.; Vessella, R.; Hess, D.L.; Kalhorn, T.F.; Higano, C.S.; True, L.D.; Nelson, P.S. Maintenance of intratumoral androgens in metastatic prostate cancer: A mechanism for castration-resistant tumor growth. Cancer Res. 2008, 68, 4447-4454. [CrossRef] [PubMed]

50. Mitsiades, N. A road map to comprehensive androgen receptor axis targeting for castration-resistant prostate cancer. Cancer Res. 2013, 73, 4599-4605. [CrossRef] [PubMed]

51. Rice, M.A.; Malhotra, S.V.; Stoyanova, T. Second-Generation Antiandrogens: From Discovery to Standard of Care in Castration Resistant Prostate Cancer. Front. Oncol. 2019, 9, 801. [CrossRef] [PubMed]

52. Gourdin, T. Recent progress in treating advanced prostate cancer. Curr. Opin. Oncol. 2020, 32, 210-215. [CrossRef] [PubMed]

53. Moussa, M.; Papatsoris, A.; Abou Chakra, M.; Sryropoulou, D.; Dellis, A. Pharmacotherapeutic strategies for castrate-resistant prostate cancer. Expert Opin. Pharmacother. 2020, 21, 1431-1448. [CrossRef] [PubMed]

54. Koivisto, P.; Kononen, J.; Palmberg, C.; Tammela, T.; Hyytinen, E.; Isola, J.; Trapman, J.; Cleutjens, K.; Noordzij, A.; Visakorpi, T.; et al. Androgen receptor gene amplification: A possible molecular mechanism for androgen deprivation therapy failure in prostate cancer. Cancer Res. 1997, 57, 314-319. [PubMed]

55. Palmberg, C.; Koivisto, P.; Kakkola, L.; Tammela, T.L.; Kallioniemi, O.P.; Visakorpi, T. Androgen receptor gene amplification at primary progression predicts response to combined androgen blockade as second line therapy for advanced prostate cancer. $J$. Urol. 2000, 164, 1992-1995. [CrossRef]

56. Kohli, M.; Li, J.; Du, M.; Hillman, D.W.; Dehm, S.M.; Tan, W.; Carlson, R.; Campion, M.B.; Wang, L.; Wang, L.; et al. Prognostic association of plasma cell-free DNA-based androgen receptor amplification and circulating tumor cells in pre-chemotherapy metastatic castration-resistant prostate cancer patients. Prostate Cancer Prostatic Dis. 2018, 21, 411-418. [CrossRef]

57. Leversha, M.A.; Han, J.; Asgari, Z.; Danila, D.C.; Lin, O.; Gonzalez-Espinoza, R.; Anand, A.; Lilja, H.; Heller, G.; Fleisher, M.; et al. Fluorescence in situ hybridization analysis of circulating tumor cells in metastatic prostate cancer. Clin. Cancer Res. 2009, 15, 2091-2209. [CrossRef]

58. Azad, A.A.; Volik, S.V.; Wyatt, A.W.; Haegert, A.; Le Bihan, S.; Bell, R.H.; Anderson, S.A.; McConeghy, B.; Shukin, R.; Bazov, J.; et al. Androgen Receptor Gene Aberrations in Circulating Cell-Free DNA: Biomarkers of Therapeutic Resistance in Castration-Resistant Prostate Cancer. Clin. Cancer Res. 2015, 21, 2315-2324. [CrossRef]

59. Salvi, S.; Casadio, V.; Conteduca, V.; Lolli, C.; Gurioli, G.; Martignano, F.; Schepisi, G.; Testoni, S.; Scarpi, E.; Amadori, D.; et al. Circulating AR copy number and outcome to enzalutamide in docetaxel-treated metastatic castration-resistant prostate cancer. Oncotarget 2016, 7, 37839-37845. [CrossRef] [PubMed]

60. Gao, W.; Bohl, C.E.; Dalton, J.T. Chemistry and structural biology of androgen receptor. Chem. Rev. 2005, 105, 3352-3370. [CrossRef]

61. Matsumoto, T.; Sakari, M.; Okada, M.; Yokoyama, A.; Takahashi, S.; Kouzmenko, A.; Kato, S. The androgen receptor in health and disease. Annu. Rev. Physiol. 2013, 75, 201-224. [CrossRef] [PubMed]

62. Tan, M.H.; Li, J.; Xu, H.E.; Melcher, K.; Yong, E.L. Androgen receptor: Structure, role in prostate cancer and drug discovery. Acta Pharmacol. Sin. 2015, 36, 3-23. [CrossRef]

63. Taplin, M.E.; Rajeshkumar, B.; Halabi, S.; Werner, C.P.; Woda, B.A.; Picus, J.; Stadler, W.; Hayes, D.F.; Kantoff, P.W.; Vogelzang, N.J.; et al. Androgen receptor mutations in androgen-independent prostate cancer: Cancer and Leukemia Group B Study 9663. J. Clin. Oncol. 2003, 21, 2673-2678. [CrossRef] [PubMed]

64. Robinson, D.; Van Allen, E.M.; Wu, Y.M.; Schultz, N.; Lonigro, R.J.; Mosquera, J.M.; Montgomery, B.; Taplin, M.E.; Pritchard, C.C.; Attard, G.; et al. Integrative clinical genomics of advanced prostate cancer. Cell 2015, 161, 1215-1228. [CrossRef]

65. Taplin, M.E.; Bubley, G.J.; Shuster, T.D.; Frantz, M.E.; Spooner, A.E.; Ogata, G.K.; Keer, H.N.; Balk, S.P. Mutation of the androgen-receptor gene in metastatic androgen-independent prostate cancer. N. Engl. J. Med. 1995, 332, 1393-1398. [CrossRef]

66. Joseph, J.D.; Lu, N.; Qian, J.; Sensintaffar, J.; Shao, G.; Brigham, D.; Moon, M.; Maneval, E.C.; Chen, I.; Darimont, B.; et al. A clinically relevant androgen receptor mutation confers resistance to second-generation antiandrogens enzalutamide and ARN-509. Cancer Discov. 2013, 3, 1020-1029. [CrossRef]

67. Korpal, M.; Korn, J.M.; Gao, X.; Rakiec, D.P.; Ruddy, D.A.; Doshi, S.; Yuan, J.; Kovats, S.G.; Kim, S.; Cooke, V.G.; et al. An F876L mutation in androgen receptor confers genetic and phenotypic resistance to MDV3100 (enzalutamide). Cancer Discov. 2013, 3, 1030-1043. [CrossRef] [PubMed]

68. Lallous, N.; Volik, S.V.; Awrey, S.; Leblanc, E.; Tse, R.; Murillo, J.; Singh, K.; Azad, A.A.; Wyatt, A.W.; LeBihan, S.; et al. Functional analysis of androgen receptor mutations that confer anti-androgen resistance identified in circulating cell-free DNA from prostate cancer patients. Genome Biol. 2016, 17, 10. [CrossRef]

69. Prekovic, S.; van Royen, M.E.; Voet, A.R.; Geverts, B.; Houtman, R.; Melchers, D.; Zhang, K.Y.; Van den Broeck, T.; Smeets, E.; Spans, L.; et al. The Effect of F877L and T878A Mutations on Androgen Receptor Response to Enzalutamide. Mol. Cancer Ther. 2016, 15, 1702-1712. [CrossRef]

70. Miyamoto, H.; Yeh, S.; Lardy, H.; Messing, E.; Chang, C. Delta5-androstenediol is a natural hormone with androgenic activity in human prostate cancer cells. Proc. Natl. Acad. Sci. USA 1998, 95, 11083-11088. [CrossRef]

71. Zhao, X.Y.; Malloy, P.J.; Krishnan, A.V.; Swami, S.; Navone, N.M.; Peehl, D.M.; Feldman, D. Glucocorticoids can promote androgen-independent growth of prostate cancer cells through a mutated androgen receptor. Nat. Med. 2000, 6, 703-706. [CrossRef] [PubMed] 
72. $\quad$ van de Wijngaart, D.J.; Molier, M.; Lusher, S.J.; Hersmus, R.; Jenster, G.; Trapman, J.; Dubbink, H.J. Systematic structure-function analysis of androgen receptor Leu701 mutants explains the properties of the prostate cancer mutant L701H. J. Biol. Chem. 2010, 285, 5097-5105. [CrossRef]

73. Steinkamp, M.P.; O’Mahony, O.A.; Brogley, M.; Rehman, H.; Lapensee, E.W.; Dhanasekaran, S.; Hofer, M.D.; Kuefer, R.; Chinnaiyan, A.; Rubin, M.A.; et al. Treatment-dependent androgen receptor mutations in prostate cancer exploit multiple mechanisms to evade therapy. Cancer Res. 2009, 69, 4434-4442. [CrossRef]

74. Barbieri, C.E.; Baca, S.C.; Lawrence, M.S.; Demichelis, F.; Blattner, M.; Theurillat, J.P.; White, T.A.; Stojanov, P.; Van Allen, E.; Stransky, N.; et al. Exome sequencing identifies recurrent SPOP, FOXA1 and MED12 mutations in prostate cancer. Nat. Genet. 2012, 44, 685-689. [CrossRef] [PubMed]

75. Conteduca, V.; Wetterskog, D.; Sharabiani, M.T.A.; Grande, E.; Fernandez-Perez, M.P.; Jayaram, A.; Salvi, S.; Castellano, D.; Romanel, A.; Lolli, C.; et al. Androgen receptor gene status in plasma DNA associates with worse outcome on enzalutamide or abiraterone for castration-resistant prostate cancer: A multi-institution correlative biomarker study. Ann. Oncol. 2017, 28, 1508-1516. [CrossRef] [PubMed]

76. Sumiyoshi, T.; Mizuno, K.; Yamasaki, T.; Miyazaki, Y.; Makino, Y.; Okasho, K.; Li, X.; Utsunomiya, N.; Goto, T.; Kobayashi, T.; et al. Clinical utility of androgen receptor gene aberrations in circulating cell-free DNA as a biomarker for treatment of castrationresistant prostate cancer. Sci. Rep. 2019, 9, 4030. [CrossRef]

77. Ledet, E.M.; Lilly, M.B.; Sonpavde, G.; Lin, E.; Nussenzveig, R.H.; Barata, P.C.; Yandell, M.; Nagy, R.J.; Kiedrowski, L.; Agarwal, N.; et al. Comprehensive Analysis of AR Alterations in Circulating Tumor DNA from Patients with Advanced Prostate Cancer. Oncologist 2020, 25, 327-333. [CrossRef] [PubMed]

78. Haile, S.; Sadar, M.D. Androgen receptor and its splice variants in prostate cancer. Cell Mol. Life Sci. 2011, 68, 3971-3981. [CrossRef]

79. Lu, C.; Luo, J. Decoding the androgen receptor splice variants. Translat. Androl. Urol. 2013, 2, 178-186.

80. Bryce, A.H.; Antonarakis, E.S. Androgen receptor splice variant 7 in castration-resistant prostate cancer: Clinical considerations. Int. J. Urol. 2016, 23, 646-653. [CrossRef]

81. Lu, C.; Brown, L.C.; Antonarakis, E.S.; Armstrong, A.J.; Luo, J. Androgen receptor variant-driven prostate cancer II: Advances in laboratory investigations. Prostate Cancer Prostatic Dis. 2020, 23, 381-397. [CrossRef] [PubMed]

82. Zhu, Y.; Luo, J. Regulation of androgen receptor variants in prostate cancer. Asian J. Urol. 2020, 7, 251-257. [CrossRef] [PubMed]

83. Luo, J. Development of AR-V7 as a putative treatment selection marker for metastatic castration-resistant prostate cancer. Asian J. Androl. 2016, 18, 580-585. [CrossRef]

84. Li, Y.; Chan, S.C.; Brand, L.J.; Hwang, T.H.; Silverstein, K.A.; Dehm, S.M. Androgen receptor splice variants mediate enzalutamide resistance in castration-resistant prostate cancer cell lines. Cancer Res. 2013, 73, 483-489. [CrossRef] [PubMed]

85. Mostaghel, E.A.; Marck, B.T.; Plymate, S.R.; Vessella, R.L.; Balk, S.; Matsumoto, A.M.; Nelson, P.S.; Montgomery, R.B. Resistance to CYP17A1 inhibition with abiraterone in castration-resistant prostate cancer: Induction of steroidogenesis and androgen receptor splice variants. Clin. Cancer Res. 2011, 17, 5913-5925. [CrossRef]

86. Sarwar, M.; Semenas, J.; Miftakhova, R.; Simoulis, A.; Robinson, B.; Gjorloff Wingren, A.; Mongan, N.P.; Heery, D.M.; Johnsson, H.; Abrahamsson, P.A.; et al. Targeted suppression of AR-V7 using PIP5K1alpha inhibitor overcomes enzalutamide resistance in prostate cancer cells. Oncotarget 2016, 7, 63065-63081. [CrossRef]

87. Cao, Q.; Song, Z.; Ruan, H.; Wang, C.; Yang, X.; Bao, L.; Wang, K.; Cheng, G.; Xu, T.; Xiao, W.; et al. Targeting the KIF4A/AR Axis to Reverse Endocrine Therapy Resistance in Castration-resistant Prostate Cancer. Clin. Cancer Res. 2020, 26, 1516-1528. [CrossRef]

88. Sun, S.; Sprenger, C.C.; Vessella, R.L.; Haugk, K.; Soriano, K.; Mostaghel, E.A.; Page, S.T.; Coleman, I.M.; Nguyen, H.M.; Sun, H.; et al. Castration resistance in human prostate cancer is conferred by a frequently occurring androgen receptor splice variant. J. Clin. Investig. 2010, 120, 2715-2730. [CrossRef]

89. Hornberg, E.; Ylitalo, E.B.; Crnalic, S.; Antti, H.; Stattin, P.; Widmark, A.; Bergh, A.; Wikstrom, P. Expression of androgen receptor splice variants in prostate cancer bone metastases is associated with castration-resistance and short survival. PLoS ONE 2011, 6, e19059. [CrossRef]

90. Zhang, X.; Morrissey, C.; Sun, S.; Ketchandji, M.; Nelson, P.S.; True, L.D.; Vakar-Lopez, F.; Vessella, R.L.; Plymate, S.R. Androgen receptor variants occur frequently in castration resistant prostate cancer metastases. PLoS ONE 2011, 6, e27970. [CrossRef] [PubMed]

91. Welti, J.; Rodrigues, D.N.; Sharp, A.; Sun, S.; Lorente, D.; Riisnaes, R.; Figueiredo, I.; Zafeiriou, Z.; Rescigno, P.; de Bono, J.S.; et al. Analytical Validation and Clinical Qualification of a New Immunohistochemical Assay for Androgen Receptor Splice Variant-7 Protein Expression in Metastatic Castration-resistant Prostate Cancer. Eur. Urol. 2016, 70, 599-608. [CrossRef] [PubMed]

92. Sharp, A.; Coleman, I.; Yuan, W.; Sprenger, C.; Dolling, D.; Rodrigues, D.N.; Russo, J.W.; Figueiredo, I.; Bertan, C.; Seed, G.; et al. Androgen receptor splice variant-7 expression emerges with castration resistance in prostate cancer. J. Clin. Investig. 2019, 129, 192-208. [CrossRef]

93. Antonarakis, E.S.; Lu, C.; Wang, H.; Luber, B.; Nakazawa, M.; Roeser, J.C.; Chen, Y.; Mohammad, T.A.; Chen, Y.; Fedor, H.L.; et al. AR-V7 and resistance to enzalutamide and abiraterone in prostate cancer. N. Engl. J. Med. 2014, 371, 1028-1038. [CrossRef]

94. Strati, A.; Zavridou, M.; Bournakis, E.; Mastoraki, S.; Lianidou, E. Expression pattern of androgen receptors, AR-V7 and AR-567es, in circulating tumor cells and paired plasma-derived extracellular vesicles in metastatic castration resistant prostate cancer. Analyst 2019, 144, 6671-6680. [CrossRef] [PubMed] 
95. Foroni, C.; Zarovni, N.; Bianciardi, L.; Bernardi, S.; Triggiani, L.; Zocco, D.; Venturella, M.; Chiesi, A.; Valcamonico, F.; Berruti, A. When Less Is More: Specific Capture and Analysis of Tumor Exosomes in Plasma Increases the Sensitivity of Liquid Biopsy for Comprehensive Detection of Multiple Androgen Receptor Phenotypes in Advanced Prostate Cancer Patients. Biomedicines 2020, 8, 131. [CrossRef] [PubMed]

96. Zhang, T.; Karsh, L.I.; Nissenblatt, M.J.; Canfield, S.E. Androgen Receptor Splice Variant, AR-V7, as a Biomarker of Resistance to Androgen Axis-Targeted Therapies in Advanced Prostate Cancer. Clin. Genitourin. Cancer 2020, 18, 1-10. [CrossRef] [PubMed]

97. Zavridou, M.; Strati, A.; Bournakis, E.; Smilkou, S.; Tserpeli, V.; Lianidou, E. Prognostic Significance of Gene Expression and DNA Methylation Markers in Circulating Tumor Cells and Paired Plasma Derived Exosomes in Metastatic Castration Resistant Prostate Cancer. Cancers 2021, 13, 780. [CrossRef] [PubMed]

98. Ware, K.E.; Garcia-Blanco, M.A.; Armstrong, A.J.; Dehm, S.M. Biologic and clinical significance of androgen receptor variants in castration resistant prostate cancer. Endocr. Relat. Cancer 2014, 21, T87-T103. [CrossRef]

99. Kallio, H.M.L.; Hieta, R.; Latonen, L.; Brofeldt, A.; Annala, M.; Kivinummi, K.; Tammela, T.L.; Nykter, M.; Isaacs, W.B.; Lilja, H.G.; et al. Constitutively active androgen receptor splice variants AR-V3, AR-V7 and AR-V9 are co-expressed in castrationresistant prostate cancer metastases. Br. J. Cancer 2018, 119, 347-356. [CrossRef]

100. Tagawa, S.T.; Antonarakis, E.S.; Gjyrezi, A.; Galletti, G.; Kim, S.; Worroll, D.; Stewart, J.; Zaher, A.; Szatrowski, T.P.; Ballman, K.V.; et al. Expression of AR-V7 and ARv(567es) in Circulating Tumor Cells Correlates with Outcomes to Taxane Therapy in Men with Metastatic Prostate Cancer Treated in TAXYNERGY. Clin. Cancer Res. 2019, 25, 1880-1888. [CrossRef]

101. Nagandla, H.; Robertson, M.J.; Putluri, V.; Putluri, N.; Coarfa, C.; Weigel, N.L. Isoform-specific Activities of Androgen Receptor and its Splice Variants in Prostate Cancer Cells. Endocrinology 2021, 162, bqaa227. [CrossRef] [PubMed]

102. Yang, J.C.; Ok, J.H.; Busby, J.E.; Borowsky, A.D.; Kung, H.J.; Evans, C.P. Aberrant activation of androgen receptor in a new neuropeptide-autocrine model of androgen-insensitive prostate cancer. Cancer Res. 2009, 69, 151-160. [CrossRef] [PubMed]

103. Heemers, H.V.; Tindall, D.J. Androgen receptor (AR) coregulators: A diversity of functions converging on and regulating the AR transcriptional complex. Endocr. Rev. 2007, 28, 778-808. [CrossRef]

104. Chandrasekar, T.; Yang, J.C.; Gao, A.C.; Evans, C.P. Mechanisms of resistance in castration-resistant prostate cancer (CRPC). Translat. Androl. Urol. 2015, 4, 365-380.

105. Foley, C.; Mitsiades, N. Moving Beyond the Androgen Receptor (AR): Targeting AR-Interacting Proteins to Treat Prostate Cancer. Horm. Cancer 2016, 7, 84-103. [CrossRef] [PubMed]

106. Obinata, D.; Takayama, K.; Takahashi, S.; Inoue, S. Crosstalk of the Androgen Receptor with Transcriptional Collaborators: Potential Therapeutic Targets for Castration-Resistant Prostate Cancer. Cancers 2017, 9, 22. [CrossRef] [PubMed]

107. Bishop, J.L.; Thaper, D.; Vahid, S.; Davies, A.; Ketola, K.; Kuruma, H.; Jama, R.; Nip, K.M.; Angeles, A.; Johnson, F.; et al. The Master Neural Transcription Factor BRN2 Is an Androgen Receptor-Suppressed Driver of Neuroendocrine Differentiation in Prostate Cancer. Cancer Discov. 2017, 7, 54-71. [CrossRef]

108. Teng, M.; Zhou, S.; Cai, C.; Lupien, M.; He, H.H. Pioneer of prostate cancer: Past, present and the future of FOXA1. Protein Cell 2021, 12, 29-38. [CrossRef] [PubMed]

109. Copeland, B.T.; Pal, S.K.; Bolton, E.C.; Jones, J.O. The androgen receptor malignancy shift in prostate cancer. Prostate 2018, 78, 521-531. [CrossRef] [PubMed]

110. Hankey, W.; Chen, Z.; Wang, Q. Shaping Chromatin States in Prostate Cancer by Pioneer Transcription Factors. Cancer Res. 2020, 80, 2427-2436. [CrossRef] [PubMed]

111. Hermanson, O.; Glass, C.K.; Rosenfeld, M.G. Nuclear receptor coregulators: Multiple modes of modification. Trends Endocrinol. Metab. 2002, 13, 55-60. [CrossRef]

112. Wang, Q.; Carroll, J.S.; Brown, M. Spatial and temporal recruitment of androgen receptor and its coactivators involves chromosomal looping and polymerase tracking. Mol. Cell 2005, 19, 631-642. [CrossRef]

113. Chung, A.C.; Zhou, S.; Liao, L.; Tien, J.C.; Greenberg, N.M.; Xu, J. Genetic ablation of the amplified-in-breast cancer 1 inhibits spontaneous prostate cancer progression in mice. Cancer Res. 2007, 67, 5965-5975. [CrossRef]

114. Xu, J.; Wu, R.C.; O'Malley, B.W. Normal and cancer-related functions of the p160 steroid receptor co-activator (SRC) family. Nat. Rev. Cancer 2009, 9, 615-630. [CrossRef]

115. Taylor, B.S.; Schultz, N.; Hieronymus, H.; Gopalan, A.; Xiao, Y.; Carver, B.S.; Arora, V.K.; Kaushik, P.; Cerami, E.; Reva, B.; et al. Integrative genomic profiling of human prostate cancer. Cancer Cell 2010, 18, 11-22. [CrossRef] [PubMed]

116. Ueda, T.; Mawji, N.R.; Bruchovsky, N.; Sadar, M.D. Ligand-independent activation of the androgen receptor by interleukin-6 and the role of steroid receptor coactivator-1 in prostate cancer cells. J. Biol. Chem. 2002, 277, 38087-38094. [CrossRef]

117. Fujimoto, N.; Miyamoto, H.; Mizokami, A.; Harada, S.; Nomura, M.; Ueta, Y.; Sasaguri, T.; Matsumoto, T. Prostate cancer cells increase androgen sensitivity by increase in nuclear androgen receptor and androgen receptor coactivators; a possible mechanism of hormone-resistance of prostate cancer cells. Cancer Investig. 2007, 25, 32-37. [CrossRef] [PubMed]

118. Karpf, A.R.; Bai, S.; James, S.R.; Mohler, J.L.; Wilson, E.M. Increased expression of androgen receptor coregulator MAGE-11 in prostate cancer by DNA hypomethylation and cyclic AMP. Mol. Cancer Res. 2009, 7, 523-535. [CrossRef] [PubMed]

119. Taylor, L.G.; Canfield, S.E.; Du, X.L. Review of major adverse effects of androgen-deprivation therapy in men with prostate cancer. Cancer 2009, 115, 2388-2399. [CrossRef]

120. Wu, Y.; Rosenberg, J.E.; Taplin, M.E. Novel agents and new therapeutics in castration-resistant prostate cancer. Curr. Opin. Oncol. 2011, 23, 290-296. [CrossRef] [PubMed] 
121. Klotz, L. Degarelix acetate for the treatment of prostate cancer. Drugs Today 2009, 45, 725-730. [CrossRef]

122. Van Poppel, H.; Abrahamsson, P.A. Considerations for the use of gonadotropin-releasing hormone agonists and antagonists in patients with prostate cancer. Int. J. Urol. 2020, 27, 830-837. [CrossRef]

123. Abufaraj, M.; Iwata, T.; Kimura, S.; Haddad, A.; Al-Ani, H.; Abusubaih, L.; Moschini, M.; Briganti, A.; Karakiewicz, P.I.; Shariat, S.F. Differential Impact of Gonadotropin-releasing Hormone Antagonist Versus Agonist on Clinical Safety and Oncologic Outcomes on Patients with Metastatic Prostate Cancer: A Meta-analysis of Randomized Controlled Trials. Eur. Urol. 2021, 79, 44-53. [CrossRef] [PubMed]

124. Liu, Y.F.; Fu, S.Q.; Yan, Y.C.; Gong, B.B.; Xie, W.J.; Yang, X.R.; Sun, T.; Ma, M. Progress in Clinical Research on GonadotropinReleasing Hormone Receptor Antagonists for the Treatment of Prostate Cancer. Drug Des. Dev. Ther. 2021, 15, 639-649. [CrossRef]

125. Schally, A.V.; Comaru-Schally, A.M.; Nagy, A.; Kovacs, M.; Szepeshazi, K.; Plonowski, A.; Varga, J.L.; Halmos, G. Hypothalamic hormones and cancer. Front. Neuroendocrinol. 2001, 22, 248-291. [CrossRef]

126. Grundker, C.; Gunthert, A.R.; Westphalen, S.; Emons, G. Biology of the gonadotropin-releasing hormone system in gynecological cancers. Eur. J. Endocrinol. 2002, 146, 1-14. [CrossRef]

127. So, W.K.; Cheng, J.C.; Poon, S.L.; Leung, P.C. Gonadotropin-releasing hormone and ovarian cancer: A functional and mechanistic overview. FEBS J. 2008, 275, 5496-5511. [CrossRef]

128. Schneider, J.S.; Rissman, E.F. Gonadotropin-releasing hormone II: A multi-purpose neuropeptide. Integr. Compar. Biol. 2008, 48, 588-595. [CrossRef] [PubMed]

129. Cheon, K.W.; Lee, H.S.; Parhar, I.S.; Kang, I.S. Expression of the second isoform of gonadotrophin-releasing hormone (GnRH-II) in human endometrium throughout the menstrual cycle. Mol. Hum. Reprod. 2001, 7, 447-452. [CrossRef] [PubMed]

130. Grundker, C.; Gunthert, A.R.; Millar, R.P.; Emons, G. Expression of gonadotropin-releasing hormone II (GnRH-II) receptor in human endometrial and ovarian cancer cells and effects of GnRH-II on tumor cell proliferation. J. Clin. Endocrinol. Metab. 2002, 87, 1427-1430. [CrossRef] [PubMed]

131. Millar, R.P. GnRH II and type II GnRH receptors. Trends Endocrinol. Metab. 2003, 14, 35-43. [CrossRef]

132. Neill, J.D.; Musgrove, L.C.; Duck, L.W. Newly recognized GnRH receptors: Function and relative role. Trends Endocrinol. Metab. 2004, 15, 383-392. [CrossRef]

133. Cheng, C.K.; Leung, P.C. Molecular biology of gonadotropin-releasing hormone (GnRH)-I, GnRH-II, and their receptors in humans. Endocr. Rev. 2005, 26, 283-306. [CrossRef]

134. Grundker, C.; Fost, C.; Fister, S.; Nolte, N.; Gunthert, A.R.; Emons, G. Gonadotropin-releasing hormone type II antagonist induces apoptosis in MCF-7 and triple-negative MDA-MB-231 human breast cancer cells in vitro and in vivo. Breast Cancer Res. 2010, 12, R49. [CrossRef] [PubMed]

135. Sower, S.A.; Chiang, Y.C.; Lovas, S.; Conlon, J.M. Primary structure and biological activity of a third gonadotropin-releasing hormone from lamprey brain. Endocrinology 1993, 132, 1125-1131. [CrossRef] [PubMed]

136. Kovacs, M.; Vincze, B.; Horvath, J.E.; Seprodi, J. Structure-activity study on the LH- and FSH-releasing and anticancer effects of gonadotropin-releasing hormone (GnRH)-III analogs. Peptides 2007, 28, 821-829. [CrossRef] [PubMed]

137. Limonta, P.; Dondi, D.; Moretti, R.M.; Fermo, D.; Garattini, E.; Motta, M. Expression of luteinizing hormone-releasing hormone mRNA in the human prostatic cancer cell line LNCaP. J. Clin. Endocrinol. Metab. 1993, 76, 797-800.

138. Ohno, T.; Imai, A.; Furui, T.; Takahashi, K.; Tamaya, T. Presence of gonadotropin-releasing hormone and its messenger ribonucleic acid in human ovarian epithelial carcinoma. Am. J. Obstet. Gynecol. 1993, 169, 605-610. [CrossRef]

139. Dondi, D.; Limonta, P.; Moretti, R.M.; Marelli, M.M.; Garattini, E.; Motta, M. Antiproliferative effects of luteinizing hormonereleasing hormone (LHRH) agonists on human androgen-independent prostate cancer cell line DU 145: Evidence for an autocrine-inhibitory LHRH loop. Cancer Res. 1994, 54, 4091-4095. [PubMed]

140. Irmer, G.; Burger, C.; Ortmann, O.; Schulz, K.D.; Emons, G. Expression of luteinizing hormone releasing hormone and its mRNA in human endometrial cancer cell lines. J. Clin. Endocrinol. Metab. 1994, 79, 916-919. [PubMed]

141. Irmer, G.; Burger, C.; Muller, R.; Ortmann, O.; Peter, U.; Kakar, S.S.; Neill, J.D.; Schulz, K.D.; Emons, G. Expression of the messenger RNAs for luteinizing hormone-releasing hormone (LHRH) and its receptor in human ovarian epithelial carcinoma. Cancer Res. 1995, 55, 817-822.

142. Kakar, S.S.; Musgrove, L.C.; Devor, D.C.; Sellers, J.C.; Neill, J.D. Cloning, sequencing, and expression of human gonadotropin releasing hormone (GnRH) receptor. Biochem. Biophys. Res. Commun. 1992, 189, 289-295. [CrossRef]

143. Neill, J.D. GnRH and GnRH receptor genes in the human genome. Endocrinology 2002, 143, 737-743. [CrossRef]

144. Kakar, S.S.; Malik, M.T.; Winters, S.J.; Mazhawidza, W. Gonadotropin-releasing hormone receptors: Structure, expression, and signaling transduction. Vitam. Horm. 2004, 69, 151-207.

145. Millar, R.P.; Lu, Z.L.; Pawson, A.J.; Flanagan, C.A.; Morgan, K.; Maudsley, S.R. Gonadotropin-releasing hormone receptors. Endocr. Rev. 2004, 25, 235-275. [CrossRef]

146. McArdle, C.A.; Franklin, J.; Green, L.; Hislop, J.N. Signalling, cycling and desensitisation of gonadotrophin-releasing hormone receptors. J. Endocrinol. 2002, 173, 1-11. [CrossRef]

147. Kraus, S.; Naor, Z.; Seger, R. Intracellular signaling pathways mediated by the gonadotropin-releasing hormone (GnRH) receptor. Arch. Med. Res. 2001, 32, 499-509. [CrossRef] 
148. Aguilar-Rojas, A.; Huerta-Reyes, M. Human gonadotropin-releasing hormone receptor-activated cellular functions and signaling pathways in extra-pituitary tissues and cancer cells (Review). Oncol. Rep. 2009, 22, 981-990. [CrossRef] [PubMed]

149. McArdle, C.A. Gonadotropin-releasing hormone receptor signaling: Biased and unbiased. Mini Rev. Med. Chem. 2012, 12, 841-850. [CrossRef] [PubMed]

150. Naor, Z.; Huhtaniemi, I. Interactions of the GnRH receptor with heterotrimeric G proteins. Front. Neuroendocrinol. 2013, 34, 88-94. [CrossRef]

151. Janjic, M.M.; Stojilkovic, S.S.; Bjelobaba, I. Intrinsic and Regulated Gonadotropin-Releasing Hormone Receptor Gene Transcription in Mammalian Pituitary Gonadotrophs. Front. Endocrinol. 2017, 8, 221. [CrossRef] [PubMed]

152. Limonta, P.; Moretti, R.M.; Marelli, M.M.; Dondi, D.; Parenti, M.; Motta, M. The luteinizing hormone-releasing hormone receptor in human prostate cancer cells: Messenger ribonucleic acid expression, molecular size, and signal transduction pathway. Endocrinology 1999, 140, 5250-5256. [CrossRef]

153. Qayum, A.; Gullick, W.; Clayton, R.C.; Sikora, K.; Waxman, J. The effects of gonadotrophin releasing hormone analogues in prostate cancer are mediated through specific tumour receptors. Br. J. Cancer 1990, 62, 96-99. [CrossRef]

154. Srkalovic, G.; Bokser, L.; Radulovic, S.; Korkut, E.; Schally, A.V. Receptors for luteinizing hormone-releasing hormone (LHRH) in Dunning R3327 prostate cancers and rat anterior pituitaries after treatment with a sustained delivery system of LHRH antagonist SB-75. Endocrinology 1990, 127, 3052-3060. [CrossRef] [PubMed]

155. Limonta, P.; Dondi, D.; Moretti, R.M.; Maggi, R.; Motta, M. Antiproliferative effects of luteinizing hormone-releasing hormone agonists on the human prostatic cancer cell line LNCaP. J. Clin. Endocrinol. Metab. 1992, 75, 207-212. [PubMed]

156. Pinski, J.; Reile, H.; Halmos, G.; Groot, K.; Schally, A.V. Inhibitory effects of analogs of luteinizing hormone-releasing hormone on the growth of the androgen-independent Dunning R-3327-AT-1 rat prostate cancer. Int. J. Cancer 1994, 59, 51-55. [CrossRef] [PubMed]

157. Franklin, J.; Hislop, J.; Flynn, A.; McArdle, C.A. Signalling and anti-proliferative effects mediated by gonadotrophin-releasing hormone receptors after expression in prostate cancer cells using recombinant adenovirus. J. Endocrinol. 2003, 176, 275-284. [CrossRef]

158. Limonta, P.; Dondi, D.; Marelli, M.M.; Moretti, R.M.; Negri-Cesi, P.; Motta, M. Growth of the androgen-dependent tumor of the prostate: Role of androgens and of locally expressed growth modulatory factors. J. Steroid Biochem. Mol. Biol. 1995, 53, 401-405. [CrossRef]

159. Marelli, M.M.; Moretti, R.M.; Dondi, D.; Motta, M.; Limonta, P. Luteinizing hormone-releasing hormone agonists interfere with the mitogenic activity of the insulin-like growth factor system in androgen-independent prostate cancer cells. Endocrinology 1999, 140, 329-334. [CrossRef]

160. Bahk, J.Y.; Hyun, J.S.; Lee, H.; Kim, M.O.; Cho, G.J.; Lee, B.H.; Choi, W.S. Expression of gonadotropin-releasing hormone (GnRH) and GnRH receptor mRNA in prostate cancer cells and effect of GnRH on the proliferation of prostate cancer cells. Urol. Res. 1998, 26, 259-264. [CrossRef] [PubMed]

161. Halmos, G.; Arencibia, J.M.; Schally, A.V.; Davis, R.; Bostwick, D.G. High incidence of receptors for luteinizing hormone-releasing hormone (LHRH) and LHRH receptor gene expression in human prostate cancers. J. Urol. 2000, 163, 623-629. [CrossRef]

162. Straub, B.; Muller, M.; Krause, H.; Schrader, M.; Goessl, C.; Heicappell, R.; Miller, K. Increased incidence of luteinizing hormonereleasing hormone receptor gene messenger RNA expression in hormone-refractory human prostate cancers. Clin. Cancer Res. 2001, 7, 2340-2343. [PubMed]

163. Szabo, J.; Vegh, A.; Racz, G.; Szende, B. Immunohistochemical demonstration of gonadotropin-releasing hormone receptors in prostate carcinoma. Urol. Oncol. 2005, 23, 399-401. [CrossRef] [PubMed]

164. Morgan, K.; Conklin, D.; Pawson, A.J.; Sellar, R.; Ott, T.R.; Millar, R.P. A transcriptionally active human type II gonadotropinreleasing hormone receptor gene homolog overlaps two genes in the antisense orientation on chromosome 1q.12. Endocrinology 2003, 144, 423-436. [CrossRef] [PubMed]

165. van Biljon, W.; Wykes, S.; Scherer, S.; Krawetz, S.A.; Hapgood, J. Type II gonadotropin-releasing hormone receptor transcripts in human sperm. Biol. Reprod. 2002, 67, 1741-1749. [CrossRef]

166. Grundker, C.; Schlotawa, L.; Viereck, V.; Eicke, N.; Horst, A.; Kairies, B.; Emons, G. Antiproliferative effects of the GnRH antagonist cetrorelix and of GnRH-II on human endometrial and ovarian cancer cells are not mediated through the GnRH type I receptor. Eur. J. Endocrinol. 2004, 151, 141-149. [CrossRef] [PubMed]

167. Montagnani Marelli, M.; Moretti, R.M.; Mai, S.; Januszkiewicz-Caulier, J.; Motta, M.; Limonta, P. Type I gonadotropin-releasing hormone receptor mediates the antiproliferative effects of GnRH-II on prostate cancer cells. J. Clin. Endocrinol. Metab. 2009, 94, 1761-1767. [CrossRef] [PubMed]

168. Kim, K.Y.; Choi, K.C.; Auersperg, N.; Leung, P.C. Mechanism of gonadotropin-releasing hormone (GnRH)-I and -II-induced cell growth inhibition in ovarian cancer cells: Role of the GnRH-I receptor and protein kinase C pathway. Endocr. Relat. Cancer 2006, 13, 211-220. [CrossRef]

169. Montagnani Marelli, M.; Moretti, R.M.; Dondi, D.; Limonta, P.; Motta, M. Effects of LHRH agonists on the growth of human prostatic tumor cells: "in vitro" and "in vivo" studies. Arch. Ital. Urol. Androl. 1997, 69, 257-263.

170. Dondi, D.; Moretti, R.M.; Montagnani Marelli, M.; Pratesi, G.; Polizzi, D.; Milani, M.; Motta, M.; Limonta, P. Growth-inhibitory effects of luteinizing hormone-releasing hormone (LHRH) agonists on xenografts of the DU 145 human androgen-independent prostate cancer cell line in nude mice. Int. J. Cancer 1998, 76, 506-511. [CrossRef] 
171. Castellon, E.; Clementi, M.; Hitschfeld, C.; Sanchez, C.; Benitez, D.; Saenz, L.; Contreras, H.; Huidobro, C. Effect of leuprolide and cetrorelix on cell growth, apoptosis, and GnRH receptor expression in primary cell cultures from human prostate carcinoma. Cancer Investig. 2006, 24, 261-268. [CrossRef]

172. Sundaram, S.; Durairaj, C.; Kadam, R.; Kompella, U.B. Luteinizing hormone-releasing hormone receptor-targeted deslorelindocetaxel conjugate enhances efficacy of docetaxel in prostate cancer therapy. Mol. Cancer Ther. 2009, 8, 1655-1665. [CrossRef] [PubMed]

173. Morgan, K.; Stavrou, E.; Leighton, S.P.; Miller, N.; Sellar, R.; Millar, R.P. Elevated GnRH receptor expression plus GnRH agonist treatment inhibits the growth of a subset of papillomavirus 18-immortalized human prostate cells. Prostate 2011, 71, 915-928. [CrossRef] [PubMed]

174. Gnanapragasam, V.J.; Darby, S.; Khan, M.M.; Lock, W.G.; Robson, C.N.; Leung, H.Y. Evidence that prostate gonadotropin-releasing hormone receptors mediate an anti-tumourigenic response to analogue therapy in hormone refractory prostate cancer. J. Pathol. 2005, 206, 205-213. [CrossRef] [PubMed]

175. Ben-Ami, I.; Yao, Z.; Naor, Z.; Seger, R. Gq protein-induced apoptosis is mediated by AKT kinase inhibition that leads to protein kinase C-induced c-Jun N-terminal kinase activation. J. Biol. Chem. 2011, 286, 31022-31031. [CrossRef]

176. Nadel, G.; Yao, Z.; Ben-Ami, I.; Naor, Z.; Seger, R. Gq-Induced Apoptosis is Mediated by AKT Inhibition That Leads to PKC-Induced JNK Activation. Cell Physiol. Biochem. 2018, 50, 121-135. [CrossRef]

177. Kraus, S.; Levy, G.; Hanoch, T.; Naor, Z.; Seger, R. Gonadotropin-releasing hormone induces apoptosis of prostate cancer cells: Role of c-Jun NH2-terminal kinase, protein kinase B, and extracellular signal-regulated kinase pathways. Cancer Res. 2004, 64, 5736-5744. [CrossRef]

178. Kraus, S.; Naor, Z.; Seger, R. Gonadotropin-releasing hormone in apoptosis of prostate cancer cells. Cancer Lett. 2006, 234, 109-123. [CrossRef] [PubMed]

179. Moretti, R.M.; Marelli, M.M.; Taylor, D.M.; Martini, P.G.V.; Marzagalli, M.; Limonta, P. Gonadotropin-Releasing Hormone Agonists Sensitize, and Resensitize, Prostate Cancer Cells to Docetaxel in a p53-Dependent Manner. PLoS ONE 2014, 9 , e93713. [CrossRef]

180. Clementi, M.; Sanchez, C.; Benitez, D.A.; Contreras, H.R.; Huidobro, C.; Cabezas, J.; Acevedo, C.; Castellon, E.A. Gonadotropin releasing hormone analogs induce apoptosis by extrinsic pathway involving p53 phosphorylation in primary cell cultures of human prostatic adenocarcinomas. Prostate 2009, 69, 1025-1033. [CrossRef]

181. Sanchez, C.A.; Mercado, A.J.; Contreras, H.R.; Cabezas, J.C.; Huidobro, C.C.; Castellon, E.A. Pharmacoperone IN3 enhances the apoptotic effect of leuprolide in prostate cancer cells by increasing the gonadotropin-releasing hormone receptor in the cell membrane. Anticancer Drugs 2012, 23, 959-969. [CrossRef]

182. Sviridonov, L.; Dobkin-Bekman, M.; Shterntal, B.; Przedecki, F.; Formishell, L.; Kravchook, S.; Rahamim-Ben Navi, L.; Bar-Lev, T.H.; Kazanietz, M.G.; Yao, Z.; et al. Differential signaling of the GnRH receptor in pituitary gonadotrope cell lines and prostate cancer cell lines. Mol. Cell. Endocrinol. 2013, 369, 107-118. [CrossRef] [PubMed]

183. Limonta, P.; Moretti, R.M.; Dondi, D.; Marelli, M.M.; Motta, M. The EGF/TGFalpha system as an autocrine growth stimulatory loop in LNCaP cells. Endocr. Relat. Cancer 1994, 1, 5-13.

184. Motta, M.; Dondi, D.; Moretti, R.M.; Marelli, M.M.; Pimpinelli, F.; Maggi, R.; Limonta, P. Role of growth factors, steroid and peptide hormones in the regulation of human prostatic tumor growth. J. Steroid Biochem. Mol. Biol. 1996, 56, 107-111. [CrossRef]

185. Krueckl, S.L.; Sikes, R.A.; Edlund, N.M.; Bell, R.H.; Hurtado-Coll, A.; Fazli, L.; Gleave, M.E.; Cox, M.E. Increased insulin-like growth factor I receptor expression and signaling are components of androgen-independent progression in a lineage-derived prostate cancer progression model. Cancer 2004, 64, 8620-8629. [CrossRef]

186. Lee, C.; Jia, Z.; Rahmatpanah, F.; Zhang, Q.; Zi, X.; McClelland, M.; Mercola, D. Role of the adjacent stroma cells in prostate cancer development and progression: Synergy between TGF-beta and IGF signaling. Biomed. Res. Int. 2014, 2014, 502093. [CrossRef] [PubMed]

187. Biernacka, K.M.; Perks, C.M.; Holly, J.M. Role of the IGF axis in prostate cancer. Minerva Endocrinol. 2012, 37, 173-185. [PubMed]

188. Wu, J.; Yu, E. Insulin-like growth factor receptor-1 (IGF-IR) as a target for prostate cancer therapy. Cancer Metastasis Rev. 2014, 33, 607-617. [CrossRef] [PubMed]

189. Msaouel, P.; Galeas, J.N.; Boiles, A.R.; Ruiz, R.R.; Koutsilieris, M. Targeting the Bone Microenvironment in Metastatic CastrationResistant Prostate Cancer. Curr. Drug Targets 2016, 17, 276-289. [CrossRef] [PubMed]

190. Qu, X.; Wu, Z.; Dong, W.; Zhang, T.; Wang, L.; Pang, Z.; Ma, W.; Du, J. Update of IGF-1 receptor inhibitor (ganitumab, dalotuzumab, cixutumumab, teprotumumab and figitumumab) effects on cancer therapy. Oncotarget 2017, 8, 29501-29518. [CrossRef]

191. Ahearn, T.U.; Peisch, S.; Pettersson, A.; Ebot, E.M.; Zhou, C.K.; Graff, R.E.; Sinnott, J.A.; Fazli, L.; Judson, G.L.; Bismar, T.A.; et al. Expression of IGF/insulin receptor in prostate cancer tissue and progression to lethal disease. Carcinogenesis 2018, 39, 1431-1437. [CrossRef] [PubMed]

192. Mita, K.; Nakahara, M.; Usui, T. Expression of the insulin-like growth factor system and cancer progression in hormone-treated prostate cancer patients. Int. J. Urol. 2000, 7, 321-329. [CrossRef] [PubMed]

193. Joshi, G.; Singh, P.K.; Negi, A.; Rana, A.; Singh, S.; Kumar, R. Growth factors mediated cell signalling in prostate cancer progression: Implications in discovery of anti-prostate cancer agents. Chem. Biol. Interact. 2015, 240, 120-133. [CrossRef] [PubMed] 
194. Montanari, M.; Rossetti, S.; Cavaliere, C.; D’Aniello, C.; Malzone, M.G.; Vanacore, D.; Di Franco, R.; La Mantia, E.; Iovane, G.; Piscitelli, R.; et al. Epithelial-mesenchymal transition in prostate cancer: An overview. Oncotarget 2017, 8, 35376-35389. [CrossRef]

195. Culig, Z. Epithelial mesenchymal transition and resistance in endocrine-related cancers. Biochim. Biophys. Acta Mol. Cell Res. 2019, 1866, 1368-1375. [CrossRef]

196. Moretti, R.M.; Marelli, M.M.; Dondi, D.; Poletti, A.; Martini, L.; Motta, M.; Limonta, P. Luteinizing hormone-releasing hormone agonists interfere with the stimulatory actions of epidermal growth factor in human prostatic cancer cell lines, LNCaP and DU 145. J. Clin. Endocrinol. Metab. 1996, 81, 3930-3937.

197. Emons, G.; Muller, V.; Ortmann, O.; Schulz, K.D. Effects of LHRH-analogues on mitogenic signal transduction in cancer cells. J. Steroid Biochem. Mol. Biol. 1998, 65, 199-206. [CrossRef]

198. Wells, A.; Souto, J.C.; Solava, J.; Kassis, J.; Bailey, K.J.; Turner, T. Luteinizing hormone-releasing hormone agonist limits DU-145 prostate cancer growth by attenuating epidermal growth factor receptor signaling. Clin. Cancer Res. 2002, 8, 1251-1257. [PubMed]

199. Iacopino, F.; Lama, G.; Angelucci, C.; Sica, G. Leuprorelin acetate affects ERK1/2 activity in prostate cancer cells. Int. J. Oncol. 2006, 29, 237-247. [CrossRef] [PubMed]

200. Jungwirth, A.; Pinski, J.; Galvan, G.; Halmos, G.; Szepeshazi, K.; Cai, R.Z.; Groot, K.; Vadillo-Buenfil, M.; Schally, A.V. Inhibition of growth of androgen-independent DU-145 prostate cancer in vivo by luteinising hormone-releasing hormone antagonist Cetrorelix and bombesin antagonists RC-3940-II and RC-3950-II. Eur. J. Cancer 1997, 33, 1141-1148. [CrossRef]

201. Lamharzi, N.; Halmos, G.; Jungwirth, A.; Schally, A.V. Decrease in the level and mRNA expression of LH-RH and EGF receptors after treatment with LH-RH antagonist cetrorelix in DU-145 prostate tumor xenografts in nude mice. Int. J. Oncol. 1998, 13, 429-435. [CrossRef]

202. Mezo, G.; Manea, M. Luteinizing hormone-releasing hormone antagonists. Expert Opin. Ther. Pat. 2009, 19, 1771-1785. [CrossRef]

203. Sakai, M.; Martinez-Arguelles, D.B.; Patterson, N.H.; Chaurand, P.; Papadopoulos, V. In search of the molecular mechanisms mediating the inhibitory effect of the GnRH antagonist degarelix on human prostate cell growth. PLoS ONE 2015, 10, e0120670. [CrossRef] [PubMed]

204. Cucchiara, V.; Yang, J.C.; Liu, C.; Adomat, H.H.; Tomlinson Guns, E.S.; Gleave, M.E.; Gao, A.C.; Evans, C.P. GnRH Antagonists Have Direct Inhibitory Effects on Castration-Resistant Prostate Cancer Via Intracrine Androgen and AR-V7 Expression. Mol. Cancer Ther. 2019, 18, 1811-1821. [CrossRef]

205. Liu, C.; Lou, W.; Yang, J.C.; Liu, L.; Armstrong, C.M.; Lombard, A.P.; Zhao, R.; Noel, O.D.V.; Tepper, C.G.; Chen, H.W.; et al. Proteostasis by STUB1/HSP70 complex controls sensitivity to androgen receptor targeted therapy in advanced prostate cancer. Nat. Commun. 2018, 9, 4700. [CrossRef]

206. Moses, M.A.; Kim, Y.S.; Rivera-Marquez, G.M.; Oshima, N.; Watson, M.J.; Beebe, K.E.; Wells, C.; Lee, S.; Zuehlke, A.D.; Shao, H.; et al. Targeting the Hsp40/Hsp70 Chaperone Axis as a Novel Strategy to Treat Castration-Resistant Prostate Cancer. Cancer Res. 2018, 78, 4022-4035. [CrossRef]

207. Liu, L.L.; Xie, N.; Sun, S.; Plymate, S.; Mostaghel, E.; Dong, X. Mechanisms of the androgen receptor splicing in prostate cancer cells. Oncogene 2014, 33, 3140-3150. [CrossRef]

208. Tummala, R.; Lou, W.; Gao, A.C.; Nadiminty, N. Quercetin Targets hnRNPA1 to Overcome Enzalutamide Resistance in Prostate Cancer Cells. Mol. Cancer Ther. 2017, 16, 2770-2779. [CrossRef] [PubMed]

209. Chen, Z.; Wu, D.; Thomas-Ahner, J.M.; Lu, C.; Zhao, P.; Zhang, Q.; Geraghty, C.; Yan, P.S.; Hankey, W.; Sunkel, B.; et al. Diverse AR-V7 cistromes in castration-resistant prostate cancer are governed by HoxB13. Proc. Natl. Acad. Sci. USA 2018, 115, 6810-6815. [CrossRef]

210. Fan, L.; Zhang, F.; Xu, S.; Cui, X.; Hussain, A.; Fazli, L.; Gleave, M.; Dong, X.; Qi, J. Histone demethylase JMJD1A promotes alternative splicing of AR variant 7 (AR-V7) in prostate cancer cells. Proc. Natl. Acad. Sci. USA 2018, 115, E4584-E4593. [CrossRef] [PubMed]

211. Millar, R.P.; Pawson, A.J.; Morgan, K.; Rissman, E.F.; Lu, Z.L. Diversity of actions of GnRHs mediated by ligand-induced selective signaling. Front. Neuroendocrinol. 2008, 29, 17-35. [CrossRef] [PubMed]

212. Darby, S.; Stockley, J.; Khan, M.M.; Robson, C.N.; Leung, H.Y.; Gnanapragasam, V.J. Expression of GnRH type II is regulated by the androgen receptor in prostate cancer. Endocr. Relat. Cancer 2007, 14, 613-624. [CrossRef]

213. Maiti, K.; Oh, D.Y.; Moon, J.S.; Acharjee, S.; Li, J.H.; Bai, D.G.; Park, H.S.; Lee, K.; Lee, Y.C.; Jung, N.C.; et al. Differential effects of gonadotropin-releasing hormone (GnRH)-I and GnRH-II on prostate cancer cell signaling and death. J. Clin. Endocrinol. Metab. 2005, 90, 4287-4298. [CrossRef]

214. Pezaro, C.; Omlin, A.; Lorente, D.; Rodrigues, D.N.; Ferraldeschi, R.; Bianchini, D.; Mukherji, D.; Riisnaes, R.; Altavilla, A.; Crespo, M.; et al. Visceral disease in castration-resistant prostate cancer. Eur. Urol. 2014, 65, 270-273. [CrossRef]

215. Den, R.B.; George, D.; Pieczonka, C.; McNamara, M. Ra-223 Treatment for Bone Metastases in Castrate-Resistant Prostate Cancer: Practical Management Issues for Patient Selection. Am. J. Clin. Oncol. 2019, 42, 399-406. [CrossRef]

216. Conteduca, V.; Mosca, A.; Brighi, N.; de Giorgi, U.; Rescigno, P. New Prognostic Biomarkers in Metastatic Castration-Resistant Prostate Cancer. Cells 2021, 10, 193. [CrossRef] [PubMed]

217. Mollica, V.; Rizzo, A.; Rosellini, M.; Marchetti, A.; Ricci, A.D.; Cimadamore, A.; Scarpelli, M.; Bonucci, C.; Andrini, E.; Errani, C.; et al. Bone Targeting Agents in Patients with Metastatic Prostate Cancer: State of the Art. Cancers 2021, $13,546$. [CrossRef] 
218. Montagnani Marelli, M.; Moretti, R.M.; Mai, S.; Procacci, P.; Limonta, P. Gonadotropin-releasing hormone agonists reduce the migratory and the invasive behavior of androgen-independent prostate cancer cells by interfering with the activity of IGF-I. Int. J. Oncol. 2007, 30, 261-271. [CrossRef]

219. Enomoto, M.; Utsumi, M.; Park, M.K. Gonadotropin-releasing hormone induces actin cytoskeleton remodeling and affects cell migration in a cell-type-specific manner in TSU-Pr1 and DU145 cells. Endocrinology 2006, 147, 530-542. [CrossRef] [PubMed]

220. Dondi, D.; Festuccia, C.; Piccolella, M.; Bologna, M.; Motta, M. GnRH agonists and antagonists decrease the metastatic progression of human prostate cancer cell lines by inhibiting the plasminogen activator system. Oncol. Rep. 2006, 15, 393-400. [CrossRef]

221. Yates, C.; Wells, A.; Turner, T. Luteinising hormone-releasing hormone analogue reverses the cell adhesion profile of EGFR overexpressing DU-145 human prostate carcinoma subline. Br. J. Cancer 2005, 92, 366-375. [CrossRef]

222. Marzagalli, M.; Fontana, F.; Raimondi, M.; Limonta, P. Cancer Stem Cells-Key Players in Tumor Relapse. Cancers 2021, 13, 376. [CrossRef]

223. Castillo, V.; Valenzuela, R.; Huidobro, C.; Contreras, H.R.; Castellon, E.A. Functional characteristics of cancer stem cells and their role in drug resistance of prostate cancer. Int. J. Oncol. 2014, 45, 985-994. [CrossRef] [PubMed]

224. Hanahan, D.; Weinberg, R.A. Hallmarks of cancer: The next generation. Cell 2011, 144, 646-674. [CrossRef] [PubMed]

225. Mukwaya, A.; Jensen, L.; Lagali, N. Relapse of pathological angiogenesis: Functional role of the basement membrane and potential treatment strategies. Exp. Mol. Med. 2021, 53, 189-201. [CrossRef] [PubMed]

226. Rajabi, M.; Mousa, S.A. The Role of Angiogenesis in Cancer Treatment. Biomedicines 2017, 5, 34. [CrossRef] [PubMed]

227. Chen, Y.; Zhang, L.; Liu, W.X.; Wang, K. VEGF and SEMA4D have synergistic effects on the promotion of angiogenesis in epithelial ovarian cancer. Cell. Mol. Biol. Lett. 2018, 23, 2. [CrossRef] [PubMed]

228. Lopez, A.; Harada, K.; Vasilakopoulou, M.; Shanbhag, N.; Ajani, J.A. Targeting Angiogenesis in Colorectal Carcinoma. Drugs 2019, 79, 63-74. [CrossRef] [PubMed]

229. Madu, C.O.; Wang, S.; Madu, C.O.; Lu, Y. Angiogenesis in Breast Cancer Progression, Diagnosis, and Treatment. J. Cancer 2020, 11, 4474-4494. [CrossRef]

230. Tian, W.; Cao, C.; Shu, L.; Wu, F. Anti-Angiogenic Therapy in the Treatment of Non-Small Cell Lung Cancer. OncoTargets Ther. 2020, 13, 12113-12129. [CrossRef]

231. Ghafouri, S.; Burkenroad, A.; Pantuck, M.; Almomani, B.; Stefanoudakis, D.; Shen, J.; Drakaki, A. VEGF inhibition in urothelial cancer: The past, present and future. World J. Urol. 2021, 39, 741-749. [CrossRef] [PubMed]

232. Wong, S.Y.; Haack, H.; Crowley, D.; Barry, M.; Bronson, R.T.; Hynes, R.O. Tumor-secreted vascular endothelial growth factor-C is necessary for prostate cancer lymphangiogenesis, but lymphangiogenesis is unnecessary for lymph node metastasis. Cancer Res. 2005, 65, 9789-9798. [CrossRef] [PubMed]

233. Melegh, Z.; Oltean, S. Targeting Angiogenesis in Prostate Cancer. Int. J. Mol. Sci. 2019, 20, 2676. [CrossRef]

234. Sarkar, C.; Goswami, S.; Basu, S.; Chakroborty, D. Angiogenesis Inhibition in Prostate Cancer: An Update. Cancers 2020, $12,2382$. [CrossRef] [PubMed]

235. Hrouda, D.; Nicol, D.L.; Gardiner, R.A. The role of angiogenesis in prostate development and the pathogenesis of prostate cancer. Urol. Res. 2003, 30, 347-355. [CrossRef] [PubMed]

236. Green, M.M.; Hiley, C.T.; Shanks, J.H.; Bottomley, I.C.; West, C.M.; Cowan, R.A.; Stratford, I.J. Expression of vascular endothelial growth factor (VEGF) in locally invasive prostate cancer is prognostic for radiotherapy outcome. Int. J. Radiat. Oncol. Biol. Phys. 2007, 67, 84-90. [CrossRef] [PubMed]

237. Moretti, R.M.; Mai, S.; Montagnani Marelli, M.; Bani, M.R.; Ghilardi, C.; Giavazzi, R.; Taylor, D.M.; Martini, P.G.; Limonta, P. Dual targeting of tumor and endothelial cells by gonadotropin-releasing hormone agonists to reduce melanoma angiogenesis. Endocrinology 2010, 151, 4643-4653. [CrossRef]

238. Li, M.; Xu, H.; Wang, J. Optimized functional and structural design of dual-target LMRAP, a bifunctional fusion protein with a 25-amino-acid antitumor peptide and GnRH Fc fragment. Acta Pharm. Sin. B 2020, 10, 262-275. [CrossRef] [PubMed]

239. Imai, A.; Tamaya, T. GnRH receptor and apoptotic signaling. Vitam. Horm. 2000, 59, 1-33.

240. Maudsley, S.; Davidson, L.; Pawson, A.J.; Chan, R.; Lopez de Maturana, R.; Millar, R.P. Gonadotropin-releasing hormone (GnRH) antagonists promote proapoptotic signaling in peripheral reproductive tumor cells by activating a Galphai-coupling state of the type I GnRH receptor. Cancer Res. 2004, 64, 7533-7544. [CrossRef] [PubMed]

241. Grundker, C.; Volker, P.; Emons, G. Antiproliferative signaling of luteinizing hormone-releasing hormone in human endometrial and ovarian cancer cells through $\mathrm{G}$ protein alpha(I)-mediated activation of phosphotyrosine phosphatase. Endocrinology 2001, 142, 2369-2380. [CrossRef]

242. Fister, S.; Gunthert, A.R.; Aicher, B.; Paulini, K.W.; Emons, G.; Grundker, C. GnRH-II antagonists induce apoptosis in human endometrial, ovarian, and breast cancer cells via activation of stress-induced MAPKs p38 and JNK and proapoptotic protein Bax. Cancer Res. 2009, 69, 6473-6481. [CrossRef]

243. Naor, Z. Signaling by G-protein-coupled receptor (GPCR): Studies on the GnRH receptor. Front. Neuroendocrinol. 2009, 30, 10-29. [CrossRef] [PubMed]

244. James, N.D.; Sydes, M.R.; Clarke, N.W.; Mason, M.D.; Dearnaley, D.P.; Spears, M.R.; Ritchie, A.W.; Parker, C.C.; Russell, J.M.; Attard, G.; et al. Addition of docetaxel, zoledronic acid, or both to first-line long-term hormone therapy in prostate cancer (STAMPEDE): Survival results from an adaptive, multiarm, multistage, platform randomised controlled trial. Lancet 2016, 387, 1163-1177. [CrossRef] 
245. Fizazi, K.; Tran, N.; Fein, L.; Matsubara, N.; Rodriguez-Antolin, A.; Alekseev, B.Y.; Ozguroglu, M.; Ye, D.; Feyerabend, S.; Protheroe, A.; et al. Abiraterone plus Prednisone in Metastatic, Castration-Sensitive Prostate Cancer. N. Engl. J. Med. 2017, 377, 352-360. [CrossRef] [PubMed]

246. James, N.D.; de Bono, J.S.; Spears, M.R.; Clarke, N.W.; Mason, M.D.; Dearnaley, D.P.; Ritchie, A.W.S.; Amos, C.L.; Gilson, C.; Jones, R.J.; et al. Abiraterone for Prostate Cancer Not Previously Treated with Hormone Therapy. N. Engl. J. Med. 2017, 377, 338-351. [CrossRef] [PubMed]

247. Armstrong, A.J.; Szmulewitz, R.Z.; Petrylak, D.P.; Holzbeierlein, J.; Villers, A.; Azad, A.; Alcaraz, A.; Alekseev, B.; Iguchi, T.; Shore, N.D.; et al. ARCHES: A Randomized, Phase III Study of Androgen Deprivation Therapy with Enzalutamide or Placebo in Men with Metastatic Hormone-Sensitive Prostate Cancer. J. Clin. Oncol. 2019, 37, 2974-2986. [CrossRef] [PubMed]

248. Chi, K.N.; Agarwal, N.; Bjartell, A.; Chung, B.H.; Pereira de Santana Gomes, A.J.; Given, R.; Juarez Soto, A.; Merseburger, A.S.; Ozguroglu, M.; Uemura, H.; et al. Apalutamide for Metastatic, Castration-Sensitive Prostate Cancer. N. Engl. J. Med. 2019, 381, 13-24. [CrossRef]

249. Davis, I.D.; Martin, A.J.; Stockler, M.R.; Begbie, S.; Chi, K.N.; Chowdhury, S.; Coskinas, X.; Frydenberg, M.; Hague, W.E.; Horvath, L.G.; et al. Enzalutamide with Standard First-Line Therapy in Metastatic Prostate Cancer. N. Engl. J. Med. 2019, 381, 121-131. [CrossRef] [PubMed]

250. Kim, T.J.; Lee, Y.H.; Koo, K.C. Current Status and Future Perspectives of Androgen Receptor Inhibition Therapy for Prostate Cancer: A Comprehensive Review. Biomolecules 2021, 11, 492. [CrossRef] [PubMed]

251. Hernando Polo, S.; Moreno Munoz, D.; Rosero Rodriguez, A.C.; Silva Ruiz, J.; Rosero Rodriguez, D.I.; Counago, F. Changing the History of Prostate Cancer with New Targeted Therapies. Biomedicines 2021, 9, 392. [CrossRef] [PubMed]

252. Oudard, S.; Fizazi, K.; Sengelov, L.; Daugaard, G.; Saad, F.; Hansen, S.; Hjalm-Eriksson, M.; Jassem, J.; Thiery-Vuillemin, A.; Caffo, O.; et al. Cabazitaxel Versus Docetaxel as First-Line Therapy for Patients with Metastatic Castration-Resistant Prostate Cancer: A Randomized Phase III Trial-FIRSTANA. J. Clin. Oncol. 2017, 35, 3189-3197. [CrossRef]

253. Antonarakis, E.S.; Piulats, J.M.; Gross-Goupil, M.; Goh, J.; Ojamaa, K.; Hoimes, C.J.; Vaishampayan, U.; Berger, R.; Sezer, A.; Alanko, T.; et al. Pembrolizumab for Treatment-Refractory Metastatic Castration-Resistant Prostate Cancer: Multicohort, OpenLabel Phase II KEYNOTE-199 Study. J. Clin. Oncol. 2020, 38, 395-405. [CrossRef]

254. Hawsawi, Y.M.; Zailaie, S.A.; Oyouni, A.A.A.; Alzahrani, O.R.; Alamer, O.M.; Aljohani, S.A.S. Prostate cancer and therapeutic challenges. J. Biol. Res. 2020, 27, 20.

255. Shore, N.D.; Drake, C.G.; Lin, D.W.; Ryan, C.J.; Stratton, K.L.; Dunshee, C.; Karsh, L.I.; Kaul, S.; Kernen, K.; Pieczonka, C.; et al. Optimizing the management of castration-resistant prostate cancer patients: A practical guide for clinicians. Prostate 2020, 80, 1159-1176. [CrossRef]

256. Bansal, D.; Reimers, M.A.; Knoche, E.M.; Pachynski, R.K. Immunotherapy and Immunotherapy Combinations in Metastatic Castration-Resistant Prostate Cancer. Cancers 2021, 13, 334. [CrossRef] [PubMed]

257. Rebello, R.J.; Oing, C.; Knudsen, K.E.; Loeb, S.; Johnson, D.C.; Reiter, R.E.; Gillessen, S.; Van der Kwast, T.; Bristow, R.G. Prostate cancer. Nature Rev. Dis. Primers 2021, 7, 9. [CrossRef]

258. Desai, K.; McManus, J.; Sharifi, N. Hormonal Therapy for Prostate Cancer. Endocr. Rev. 2021, bnab002. [CrossRef]

259. Scher, H.I.; Fizazi, K.; Saad, F.; Taplin, M.E.; Sternberg, C.N.; Miller, K.; de Wit, R.; Mulders, P.; Chi, K.N.; Shore, N.D.; et al. Increased survival with enzalutamide in prostate cancer after chemotherapy. N. Engl. J. Med. 2012, 367, 1187-1197. [CrossRef]

260. Beer, T.M.; Armstrong, A.J.; Rathkopf, D.E.; Loriot, Y.; Sternberg, C.N.; Higano, C.S.; Iversen, P.; Bhattacharya, S.; Carles, J.; Chowdhury, S.; et al. Enzalutamide in metastatic prostate cancer before chemotherapy. N. Engl. J. Med. 2014, 371, 424-433. [CrossRef]

261. Penson, D.F.; Armstrong, A.J.; Concepcion, R.; Agarwal, N.; Olsson, C.; Karsh, L.; Dunshee, C.; Wang, F.; Wu, K.; Krivoshik, A.; et al. Enzalutamide Versus Bicalutamide in Castration-Resistant Prostate Cancer: The STRIVE Trial. J. Clin. Oncol. 2016, 34, 2098-2106. [CrossRef] [PubMed]

262. Hussain, M.; Fizazi, K.; Saad, F.; Rathenborg, P.; Shore, N.; Ferreira, U.; Ivashchenko, P.; Demirhan, E.; Modelska, K.; Phung, D.; et al. Enzalutamide in Men with Nonmetastatic, Castration-Resistant Prostate Cancer. N. Engl. J. Med. 2018, 378, 2465-2474. [CrossRef]

263. Smith, M.R.; Antonarakis, E.S.; Ryan, C.J.; Berry, W.R.; Shore, N.D.; Liu, G.; Alumkal, J.J.; Higano, C.S.; Chow Maneval, E.; Bandekar, R.; et al. Phase 2 Study of the Safety and Antitumor Activity of Apalutamide (ARN-509), a Potent Androgen Receptor Antagonist, in the High-risk Nonmetastatic Castration-resistant Prostate Cancer Cohort. Eur. Urol. 2016, 70, 963-970. [CrossRef] [PubMed]

264. Saad, F.; Cella, D.; Basch, E.; Hadaschik, B.A.; Mainwaring, P.N.; Oudard, S.; Graff, J.N.; McQuarrie, K.; Li, S.; Hudgens, S.; et al. Effect of apalutamide on health-related quality of life in patients with non-metastatic castration-resistant prostate cancer: An analysis of the SPARTAN randomised, placebo-controlled, phase 3 trial. Lancet Oncol. 2018, 19, 1404-1416. [CrossRef]

265. Fizazi, K.; Smith, M.R.; Tombal, B. Clinical Development of Darolutamide: A Novel Androgen Receptor Antagonist for the Treatment of Prostate Cancer. Clin. Genitourin. Cancer 2018, 16, 332-340. [CrossRef] [PubMed]

266. de Bono, J.S.; Logothetis, C.J.; Molina, A.; Fizazi, K.; North, S.; Chu, L.; Chi, K.N.; Jones, R.J.; Goodman, O.B., Jr.; Saad, F.; et al. Abiraterone and increased survival in metastatic prostate cancer. N. Engl. J. Med. 2011, 364, 1995-2005. [CrossRef]

267. Ryan, C.J.; Smith, M.R.; de Bono, J.S.; Molina, A.; Logothetis, C.J.; de Souza, P.; Fizazi, K.; Mainwaring, P.; Piulats, J.M.; Ng, S.; et al. Abiraterone in metastatic prostate cancer without previous chemotherapy. N. Engl. J. Med. 2013, 368, 138-148. [CrossRef] 
268. Ryan, C.J.; Smith, M.R.; Fizazi, K.; Saad, F.; Mulders, P.F.; Sternberg, C.N.; Miller, K.; Logothetis, C.J.; Shore, N.D.; Small, E.J.; et al. Abiraterone acetate plus prednisone versus placebo plus prednisone in chemotherapy-naive men with metastatic castrationresistant prostate cancer (COU-AA-302): Final overall survival analysis of a randomised, double-blind, placebo-controlled phase 3 study. Lancet Oncol. 2015, 16, 152-160. [CrossRef]

269. Fallara, G.; Lissbrant, I.F.; Styrke, J.; Montorsi, F.; Garmo, H.; Stattin, P. Observational study on time on treatment with abiraterone and enzalutamide. PLoS ONE 2020, 15, e0244462. [CrossRef]

270. Lawrentschuk, N.; Fernandes, K.; Bell, D.; Barkin, J.; Fleshner, N. Efficacy of a second line luteinizing hormone-releasing hormone agonist after advanced prostate cancer biochemical recurrence. J. Urol. 2011, 185, 848-854. [CrossRef] [PubMed]

271. Jang, H.S.; Koo, K.C.; Cho, K.S.; Chung, B.H. Survival Outcomes of Concurrent Treatment with Docetaxel and Androgen Deprivation Therapy in Metastatic Castration-Resistant Prostate Cancer. Yonsei Med. J. 2016, 57, 1070-1078. [CrossRef]

272. Merseburger, A.S.; Hupe, M.C. An Update on Triptorelin: Current Thinking on Androgen Deprivation Therapy for Prostate Cancer. Adv. Ther. 2016, 33, 1072-1093. [CrossRef]

273. Tombal, B.; Cornel, E.B.; Persad, R.; Stari, A.; Gomez Veiga, F.; Schulman, C. Clinical Outcomes and Testosterone Levels Following Continuous Androgen Deprivation in Patients with Relapsing or Locally Advanced Prostate Cancer: A Post Hoc Analysis of the ICELAND Study. J. Urol. 2017, 198, 1054-1060. [CrossRef]

274. Crawford, E.D.; Tombal, B.; Keane, T.; Boccardo, F.; Miller, K.; Shore, N.; Moul, J.W.; Damber, J.E.; Collette, L.; Persson, B.E. FSH suppression and tumour control in patients with prostate cancer during androgen deprivation with a GnRH agonist or antagonist. Scand. J. Urol. 2018, 52, 349-357. [CrossRef] [PubMed]

275. Klotz, L.; Boccon-Gibod, L.; Shore, N.D.; Andreou, C.; Persson, B.E.; Cantor, P.; Jensen, J.K.; Olesen, T.K.; Schroder, F.H. The efficacy and safety of degarelix: A 12-month, comparative, randomized, open-label, parallel-group phase III study in patients with prostate cancer. BJU Int. 2008, 102, 1531-1538. [CrossRef]

276. Tombal, B.; Miller, K.; Boccon-Gibod, L.; Schroder, F.; Shore, N.; Crawford, E.D.; Moul, J.; Jensen, J.K.; Kold Olesen, T.; Persson, B.E. Additional analysis of the secondary end point of biochemical recurrence rate in a phase 3 trial (CS21) comparing degarelix $80 \mathrm{mg}$ versus leuprolide in prostate cancer patients segmented by baseline characteristics. Eur. Urol. 2010, 57, 836-842. [CrossRef] [PubMed]

277. Clinton, T.N.; Woldu, S.L.; Raj, G.V. Degarelix versus luteinizing hormone-releasing hormone agonists for the treatment of prostate cancer. Expert Opin. Pharmacother. 2017, 18, 825-832. [CrossRef] [PubMed]

278. Sugimura, R.; Kawahara, T.; Miyoshi, Y.; Yao, M.; Chiba, S.; Uemura, H. A Case of Switching from GnRH Agonist to Antagonist for Castration Resistant Prostate Cancer Control. Case Rep. Oncol. 2019, 12, 688-692. [CrossRef]

279. Atchia, K.S.; Wallis, C.J.D.; Fleshner, N.; Toren, P. Switching from a gonadotropin-releasing hormone (GnRH) agonist to a GnRH antagonist in prostate cancer patients: A systematic review and meta-analysis. Can. Urol. Assoc. J. 2020, 14, 36-41.

280. Kunath, F.; Borgmann, H.; Blumle, A.; Keck, B.; Wullich, B.; Schmucker, C.; Sikic, D.; Roelle, C.; Schmidt, S.; Wahba, A.; et al. Gonadotropin-releasing hormone antagonists versus standard androgen suppression therapy for advanced prostate cancer $\mathrm{A}$ systematic review with meta-analysis. BMJ Open 2015, 5, e008217. [CrossRef]

281. Pham, T.; Sadowski, M.C.; Li, H.; Richard, D.J.; d'Emden, M.C.; Richard, K. Advances in hormonal therapies for hormone naive and castration-resistant prostate cancers with or without previous chemotherapy. Exp. Hematol. Oncol. 2015, 5, 15. [CrossRef]

282. Schally, A.V.; Engel, J.B.; Emons, G.; Block, N.L.; Pinski, J. Use of analogs of peptide hormones conjugated to cytotoxic radicals for chemotherapy targeted to receptors on tumors. Curr. Drug Deliv. 2011, 8, 11-25. [CrossRef] [PubMed]

283. Engel, J.B.; Tinneberg, H.R.; Rick, F.G.; Berkes, E.; Schally, A.V. Targeting of Peptide Cytotoxins to LHRH Receptors For Treatment of Cancer. Curr. Drug Targets 2016, 17, 488-494. [CrossRef] [PubMed]

284. Fodor, K.; Dobos, N.; Schally, A.; Steiber, Z.; Olah, G.; Sipos, E.; Szekvolgyi, L.; Halmos, G. The targeted LHRH analog AEZS-108 alters expression of genes related to angiogenesis and development of metastasis in uveal melanoma. Oncotarget 2020, 11, 175-187. [CrossRef]

285. Letsch, M.; Schally, A.V.; Szepeshazi, K.; Halmos, G.; Nagy, A. Preclinical evaluation of targeted cytotoxic luteinizing hormonereleasing hormone analogue AN-152 in androgen-sensitive and insensitive prostate cancers. Clin. Cancer Res. 2003, 9, 4505-4513.

286. Engel, J.; Emons, G.; Pinski, J.; Schally, A.V. AEZS-108: A targeted cytotoxic analog of LHRH for the treatment of cancers positive for LHRH receptors. Expert Opin. Investig. Drugs 2012, 21, 891-899. [CrossRef] [PubMed]

287. Popovics, P.; Schally, A.V.; Szalontay, L.; Block, N.L.; Rick, F.G. Targeted cytotoxic analog of luteinizing hormone-releasing hormone (LHRH), AEZS-108 (AN-152), inhibits the growth of DU-145 human castration-resistant prostate cancer in vivo and in vitro through elevating p21 and ROS levels. Oncotarget 2014, 5, 4567-4578. [CrossRef]

288. Liu, S.V.; Tsao-Wei, D.D.; Xiong, S.; Groshen, S.; Dorff, T.B.; Quinn, D.I.; Tai, Y.C.; Engel, J.; Hawes, D.; Schally, A.V.; et al. Phase I, dose-escalation study of the targeted cytotoxic LHRH analog AEZS-108 in patients with castration- and taxane-resistant prostate cancer. Clin. Cancer Res. 2014, 20, 6277-6283. [CrossRef] [PubMed]

289. Yu, S.S.; Athreya, K.; Liu, S.V.; Schally, A.V.; Tsao-Wei, D.; Groshen, S.; Quinn, D.I.; Dorff, T.B.; Xiong, S.; Engel, J.; et al. A Phase II Trial of AEZS-108 in Castration- and Taxane-Resistant Prostate Cancer. Clin. Genitourin. Cancer 2017, 15, 742-749. [CrossRef]

290. Karampelas, T.; Argyros, O.; Sayyad, N.; Spyridaki, K.; Pappas, C.; Morgan, K.; Kolios, G.; Millar, R.P.; Liapakis, G.; Tzakos, A.G.; et al. GnRH-Gemcitabine conjugates for the treatment of androgen-independent prostate cancer: Pharmacokinetic enhancements combined with targeted drug delivery. Bioconjug. Chem. 2014, 25, 813-823. [CrossRef] 
291. Argyros, O.; Karampelas, T.; Asvos, X.; Varela, A.; Sayyad, N.; Papakyriakou, A.; Davos, C.H.; Tzakos, A.G.; Fokas, D.; Tamvakopoulos, C. Peptide-Drug Conjugate GnRH-Sunitinib Targets Angiogenesis Selectively at the Site of Action to Inhibit Tumor Growth. Cancer Res. 2016, 76, 1181-1192. [CrossRef] [PubMed]

292. Marelli, M.M.; Manea, M.; Moretti, R.M.; Marzagalli, M.; Limonta, P. Oxime bond-linked daunorubicin-GnRH-III bioconjugates exert antitumor activity in castration-resistant prostate cancer cells via the type I GnRH receptor. Int. J. Oncol. 2015, 46, 243-253. [CrossRef]

293. Rachner, T.D.; Tsourdi, E.; Hofbauer, L.C. Apalutamide and Metastasis-free Survival in Prostate Cancer. N. Engl. J. Med. 2018, 378, 2541-2542.

294. Smith, M.R.; Saad, F.; Chowdhury, S.; Oudard, S.; Hadaschik, B.A.; Graff, J.N.; Olmos, D.; Mainwaring, P.N.; Lee, J.Y.; Uemura, H.; et al. Apalutamide Treatment and Metastasis-free Survival in Prostate Cancer. N. Engl. J. Med. 2018, 378, 1408-1418. [CrossRef]

295. Fizazi, K.; Shore, N.; Tammela, T.L.; Ulys, A.; Vjaters, E.; Polyakov, S.; Jievaltas, M.; Luz, M.; Alekseev, B.; Kuss, I.; et al. Darolutamide in Nonmetastatic, Castration-Resistant Prostate Cancer. N. Engl. J. Med. 2019, 380, 1235-1246. [CrossRef]

296. Small, E.J.; Saad, F.; Chowdhury, S.; Oudard, S.; Hadaschik, B.A.; Graff, J.N.; Olmos, D.; Mainwaring, P.N.; Lee, J.Y.; Uemura, H.; et al. Apalutamide and overall survival in non-metastatic castration-resistant prostate cancer. Ann. Oncol. 2019, 30, 1813-1820. [CrossRef]

297. Beltran, H.; Romanel, A.; Conteduca, V.; Casiraghi, N.; Sigouros, M.; Franceschini, G.M.; Orlando, F.; Fedrizzi, T.; Ku, S.Y.; Dann, E.; et al. Circulating tumor DNA profile recognizes transformation to castration-resistant neuroendocrine prostate cancer. J. Clin. Investig. 2020, 130, 1653-1668. [CrossRef] [PubMed]

298. Wu, Z.; Wang, K.; Yang, Z.; Pascal, L.E.; Nelson, J.B.; Takubo, K.; Wipf, P.; Wang, Z. A novel androgen receptor antagonist JJ-450 inhibits enzalutamide-resistant mutant AR(F876L) nuclear import and function. Prostate 2020, 80, 319-328. [CrossRef]

299. Bhole, R.P.; Chikhale, R.V.; Wavhale, R.D.; Asmary, F.A.; Almutairi, T.M.; Alhajri, H.M.; Bonde, C.G. Design, synthesis and evaluation of novel enzalutamide analogues as potential anticancer agents. Heliyon 2021, 7, e06227. [CrossRef]

300. Narayanan, R.; Ponnusamy, S.; Miller, D.D. Destroying the androgen receptor (AR)-potential strategy to treat advanced prostate cancer. Oncoscience 2017, 4, 175-177. [CrossRef] [PubMed]

301. Merseburger, A.S.; Waldron, N.; Ribal, M.J.; Heidenreich, A.; Perner, S.; Fizazi, K.; Sternberg, C.N.; Mateo, J.; Wirth, M.P.; Castro, E.; et al. Genomic Testing in Patients with Metastatic Castration-resistant Prostate Cancer: A Pragmatic Guide for Clinicians. Eur. Urol. 2021, 79, 519-529. [CrossRef] [PubMed]

302. Schmidt, K.T.; Huitema, A.D.R.; Chau, C.H.; Figg, W.D. Resistance to second-generation androgen receptor antagonists in prostate cancer. Nat. Rev. Urol. 2021, 18, 209-226. [CrossRef] [PubMed]

303. Tai, Y.L.; Lin, C.J.; Li, T.K.; Shen, T.L.; Hsieh, J.T.; Chen, B.P.C. The role of extracellular vesicles in prostate cancer with clinical applications. Endocr. Relat. Cancer 2020, 27, R133-R144. [CrossRef] [PubMed] 